\title{
The Trịnh Công Sơn Phenomenon
}

John C. Schafer

Peace is the root of music. ${ }^{l}$

-Nguyễn Trãi (1 $5^{\text {th }}$ century)

Those who write the songs

are more important than

those who write the laws.

-attributed to both Pascal and Napoleon

I first went to Vietnam in the summer of 1968 as a volunteer with International Voluntary Services. Assigned to teach English at Phan Chu Trinh Secondary School in Đà Nẵng, I began the task of learning a new language and culture. Vietnamese, especially students, love to put on cultural performances and I attended many. At these performances girls who in class dissolved in shyness when asked to repeat a simple English phrase sang boldly and professionally for large, appreciative audiences. In the late 60s one heard music not just at school functions but all around Đà Nẵng and other cities in South Vietnam. In coffee shops and restaurants songs emanating from large reel-to-reel tape recorders competed with the roar of Honda motorcycles and military trucks passing by on the dusty streets outside.

Many of these songs were composed by a songwriter and singer named Trịnh Công Sơn. If the event were organized by school officials, singers usually would sing some of his love songs that didn't mention the war, but at unofficial gatherings they would sing a different kind of love song, a song like "Love Song of a Mad Person," which begins

I love someone killed in the Battle of Pleime,

I love someone killed in Battlezone D,

Killed at Đồng xoài, killed in Hanoi,

Killed suddenly in the DMZ.

And continues in this way:

I want to love you, to love Vietnam-

In the storm I whispered your name,

A Vietnamese name,

Bound to you by our golden-skin tongue.

In this song we see some of the themes that Trịnh Công Sơn returned to again and again: the sadness of war, the importance of love-love between people and love for Vietnam, the native land-and a concern for the fate of people, the people of Vietnam, and by extension for all humankind.

Trịnh Công Sơn died six years ago, finally succumbing at the age of 62 to diabetes and other

\footnotetext{
${ }^{1}$ Quoted by Phong T. Nguyen in his "Introduction" to New Perspectives on Vietnamese Music (1991, vi). Nguyễn Trãi was a poet and also a military advisor to Lê Lợi who defeated the Chinese in 1427 and proclaimed himself king in 1428.
} 
ailments clearly aggravated by too much drink and too many cigarettes. Throughout Vietnam and in the cities of the Vietnamese diaspora-from Melbourne to Toronto, from Paris to Los Angeles and San Josethere was an outpouring of grief at his passing and of appreciation for the approximately 600 songs he had left behind. In Ho Chi Minh City thousands joined his funeral procession and everywhere there were cultural performances, some of them taped and shown on TV, featuring young singers singing his songs to say good-by to someone who had touched the hearts of millions. After attending a sold-out performance, "An Evening of Music to Remember Trịnh Công Sơn," at the old French opera house in Hanoi, the splendidly refurbished "Great Theater," on April 29, 2001, I decided to seek reasons for what Vietnamese commentators call "The Trịnh Công Sơn Phenomenon"-the extraordinary popularity of Trịnh Công Sơn and his music.

To call this singer's impact phenomenal is not to indulge in hyperbole. Nhật Tiến, a writer who now lives in California, calls Trịnh Công Sơn's music "the artistic work that had the clearest influence" because "it penetrated life directly" $(1989,55)$. He was most influential during the the 1960s and 70s and his most fervent admirers were Vietnamese from the region controlled by the former Republic of Vietnam (RVN). During the war Northerners were forbidden to listen to music from the South. ${ }^{2}$ After the country was reunified in 1975, however, Trịnh Công Sơn developed a national following and at the time of his death he was one of the best known songwriters in Vietnam. Though he composed what in English would be called popular music ${ }^{3}$ - songs for people from all walks of life, not just a scholarly elite-well-known writers and critics call him a poet and have written learned articles about him. The distinguished literary critic Hoàng Ngọc Hiến considers Trịnh Công Sơn's song "At Night I Feel Like a Waterfall" to be one of the best love poems of the twentieth century (see Nguyễn Trọng Tạo 2002, 13).

For all these reasons the Trịnh Công Sơn phenomenon merits investigation. What follows is my explanation for Trịnh Công Sơn's popularity, based mostly on what I've learned from conversations with Vietnamese friends and relatives over the years and from published accounts by Vietnamese that have appeared since his death. ${ }^{4}$ I conclude that there are at least seven reasons for the Trịnh Công Sơn phenomenon: the freshness of his early love songs, his evocation of Buddhist themes, the rhetorical context of South Vietnam during the American War, the ethos or persona that Trịnh Công Sơn projected, his discovery of the talented singer Khánh Ly, the emergence of the cassette tape recorder, and Trịnh Công Sơn's ability to adapt after the war to a new political climate. After providing a brief biographical sketch of his younger years, I'll develop these points more fully.

\section{Early Years ${ }^{5}$}

Sơn's ${ }^{6}$ home village was Minh Hương on the outskirts of Huế in central Vietnam. This village's name, "village of the Ming," suggests something about his distant ancestry: Son is descended on his

\footnotetext{
${ }^{2}$ Terminology can be confusing in discussing the regions of Vietnam. The temporary demarcation line at the $17^{\text {th }}$ parallel that from 1954 to 1975 separated the Democratic Republic of Vietnam (DRV) from the Republic of Vietnam (RVN) split the central region. "South Vietnam" or the RVN therefore included Vietnamese from central and south Vietnam (and also northern refugees). Vietnamese usually refer to the area south of the $17^{\text {th }}$ parallel as Miền Nam, the Southern Region. I will refer to this area as South Vietnam, or the South, and to the southern part of South Vietnam (Nam Bộ) as south Vietnam. Similarly, "Southerners" refers to people living south of the $17^{\text {th }}$ parallel; "southerners" to people living in Nam Bộ.

${ }^{3}$ See my section "The Cassette Recorder" for a discussion of how the English term "popular singer" applies to Trịnh Công Sơn.

${ }^{4}$ Most books about Trịnh Công Sơn published after he died include both newly written articles and also reprints of articles published previously elsewhere. For the latter, in my author-date parenthetical citations within the body of my article, I list first the date of the collection in which the article is reprinted, then the date of original publication.

${ }^{5}$ For this account of Sơn's early life I've drawn on Đặng Tiến 2001a, Hoàng Phủ Ngọc Tường 2001/1995, Nguyễn Đắc Xuân 2001, Nguyễn Thanh Ty 2001 and 2004, Nhật Lệ 2001/1999, Trịnh Cung 2001, and Sâm Thương 2004.

${ }^{6}$ I will sometimes refer to Trịnh Công Sơn as Sơn, his given name, to avoid repeating his full name. It is not customary to refer to Vietnamese using only the family name.
} 
father's side from Chinese associated with the Ming dynasty who settled in Vietnam in the seventeenth century when the Manchus defeated the Ming and established the Ch'ing dynasty. Sorn was born in 1939 not, as it turned out, in Minh Huong but in Đắc Lắc Province in the central highlands where his father, a businessman, had moved the family to explore business opportunities. The family returned to Huế in 1943 when economic pressures brought on by the Second World War forced his father to leave the highlands.

Sơn attended local elementary schools and was studying in a French lycée in Huế when tragedy befell the family. Son's father, who ran a bicycle parts business and also worked secretly for the revolutionary movement, was killed when he crashed his Vespa returning from Quảng Trị. This was 1955 and Son, 16 at the time, was the oldest of seven children and his mother was expecting an eighth. Though the death of his father was an emotional and economic blow to Sorn and his family, he was able to continue his studies. During the academic year 1956-57 he studied at the Providence School (Trường Thiên hựu) run by the Catholic diocese in Huế. After passing his exams and receiving his first level baccalaureate degree, he moved to Saigon where he studied philosophy at the Lycée Chasseloup-Laubat. So he could avoid the draft some friends helped him get into the Qui Nhơn School of Education. After graduating in 1964, he taught for three years in a remote school primarily for ethnic minorities in the highlands near Đà Lạt where he composed some of his most famous songs.

Sơn loved music from an early age. He played the mandolin and the bamboo flute before getting his first guitar when he was twelve. "I turned to music probably because I loved life," Sơn has written, "but a twist of fate also played a part" (2001/1997a, 202). While studying in Saigon Sơn returned to Huế on a holiday and practiced judo with his younger brother. He was hurt in the chest and his recovery took three years. The accident prevented him from ever getting his second level baccalaureate but it provided time for him to practice composing. It is clear that he never planned to make music his career. He has described this time in his life after his father died when, though he didn't know it, he was posed on the threshold of fame:

I didn't take up music with the idea of making it my career. I remember I wrote my first songs to express some inner feelings. ... That was in the years 56-57, a time of disordered dreams, of frivolous youthful thoughts. In the greenness of this youthful time, like a fruit at the start of the season, I loved music but had absolutely no ambition to be a musician. ${ }^{7}$

\section{The Early Love Songs}

Though the Trịnh Công Sơn phenomenon didn't really begin until the mid 60s when his antiwar songs became popular, it was some early love songs that first sparked interest in the young composersongs like "Wet Eye Lashes," "The Sea Remembers," "Diễm of the Past," 8 and "Sad Love." 9 Mystery has always surrounded many of Son's songs, prompted by unanswered questions regarding their inspiration, and this is especially true of his love songs. People have wanted to know the identity of the girl who inspired the song. Stories circulated, gradually assuming the quality of myth, and they helped to generate interest in the singer. In recent years Son and his close friends have cleared up some of the mysteries for a few songs. Sơn, for example, has explained that "Wet Eye Lashes" was written as a gift for a singer named Thanh Thúy whom Sơn heard sing "Autumn Rain Drops," ${ }^{10}$ crying as she sang because her mother was at home dying of tuberculosis (2001/1990, 275). And "Diễm of the Past,"

\footnotetext{
${ }^{7}$ Quoted by Đặng Tiến 2001a, 10. The original source is Trịnh Công Sơn: Nhạc và đời (Trịnh Công Sơn: His music and life) (Hậu Giang: Tổng hợp).

${ }^{8}$ See Appendix II for a translation of "Diễm of the Past," "A Lullaby of Cannons for the Night," and "A Place for Leaving and Returning." For translations of fourteen of Sơn's antiwar songs, see Do Vinh Tai and Scigliano 1997.

${ }^{9}$ In Appendix I, I give the Vietnamese titles for all the songs I mention.

10 "Autumn Rain Drops" (Giọt mưa thu) is a prewar song. See explanation in subsequent text.
} 
perhaps the most famous of all Sơn's love songs, and one of the best known of all modern Vietnamese love songs, was inspired, Sơn has explained, by a girl named Diễm whom Sơn watched from the balcony of his house in Huế (shown in the picture below) as she walked along Nguyễn Trường Tộ Street to her classes at the University (2001/1997b, 178-180).

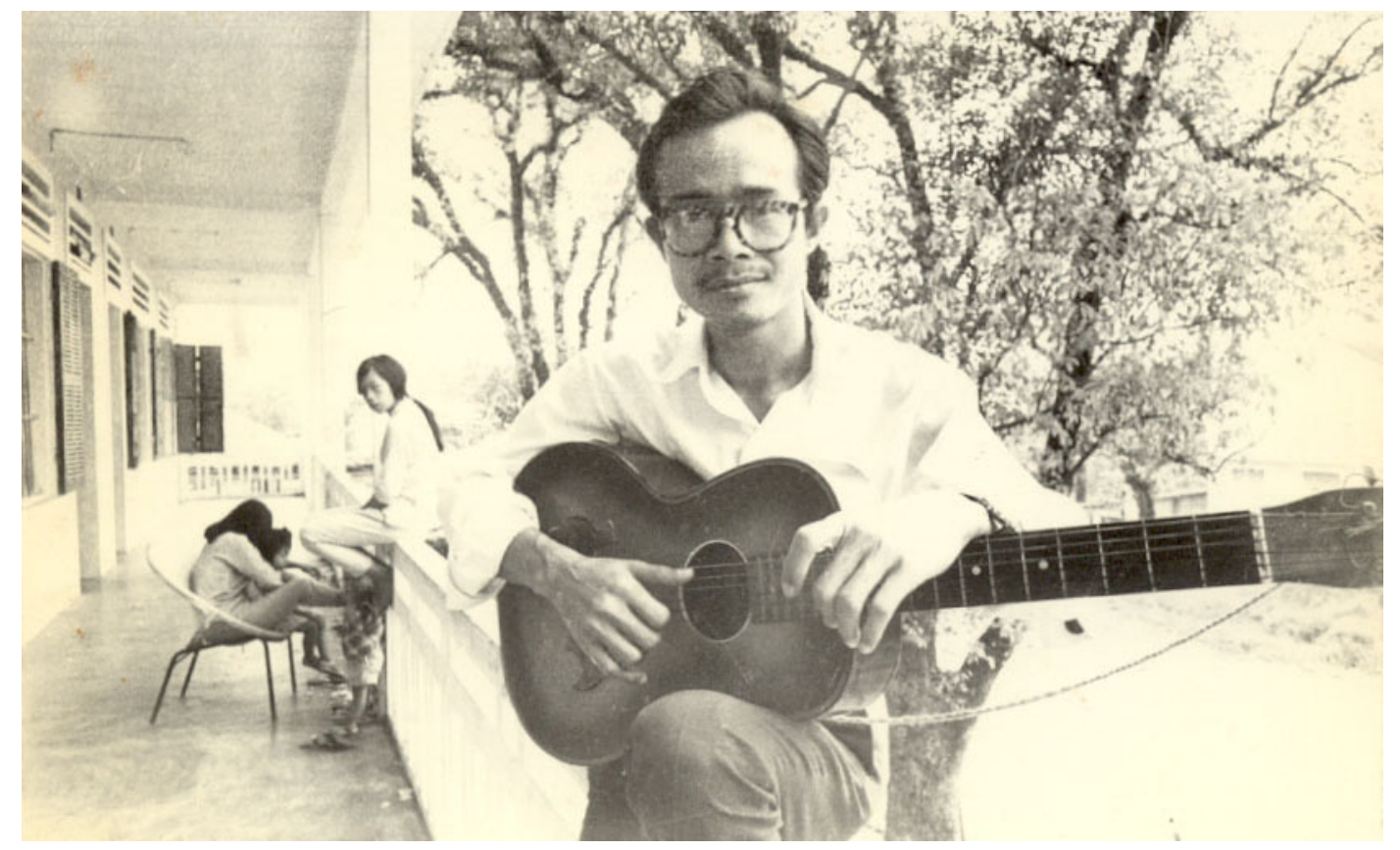

Trịnh Công Sơn on the balcony of his home on Nguyễn Trường Tộ Street in Huế, circa 1969.

What was it about these early love songs, besides the mysteries surrounding their inspiration, that made them so appealing? Sơn's contemporaries explain that they were appealing because they struck his listeners, young people in the Southern cities increasingly exposed to European and American songs, as newer than (mói hơn) songs by other Vietnamese composers. Most of these older-sounding songs were what Vietnamese refer to as "prewar" (tiền chiến) songs, a misleading term for several reasons. It is misleading first because it refers not only to songs written before the war against the French but also to songs written during and soon after it. It is also misleading because it is generally used to refer only to sentimental love songs composed during this period, not to, for example, patriotic songs. Probably the term "prewar" became popular because many songs composed during this period resembled in theme and sentiment what were called prewar poems (tho tiền chiến) composed in the 30s and 40s (Gibbs 1998a), poems which were written by a group of poets heavily influenced by nineteenth-century French romantic writers-Alphonse de Larmartine, Alfred Vigny, and Alfred de Musset, for example. Many prewar songs were prewar poems set to music. Important for our purposes is the fact that prewar songs were still popular in the 50s when Trịnh Công Sơn began to compose. In fact, "Autumn Rain Drops," the song that Thanh Thúy was singing in 1958 when she inspired Sơn to compose his first famous love song, "Wet Eyelashes," was a prewar song composed by Đặng Thế Phong in 1939. ${ }^{11}$

Trịnh Công Sơn was certainly not the first composer of what Vietnamese refer to as modern music (tân nhac) or renovated or reformed music (nhac cải cách), terms used interchangeably to describe a new Western-style music composed by Vietnamese that first emerged in the late 1930s (Gibbs 1998b). Prewar songs are considered modern or renovated songs; they form a subcategory, their

\footnotetext{
${ }^{11}$ For a description of this song and the influence of its composer, see Pham Duy 1994, 80-87; for an English translation, see Gibbs 2003a.
} 
romantic quality distinguishing them from other modern music - patriotic songs, for example. Vietnamese contrast modern songs to folk songs, called dân ca, a category that includes lullabies ( $r u$ con), rice-planting and boat-rowing songs (hò), operatic songs (hát chèo) and songstress songs (hát ca trù or hát ả đào) (Phạm Duy 1990, Phong T. Nguyen 1991). When the French introduced Western music, Vietnamese composers first wrote Vietnamese words for French tunes but in the late 1930s they began to compose modern Vietnamese songs, which is when the terms tân nhạc (modern music) and nhạ cải cách (renovated music) began to be used. Because, however, these first composers of modern Vietnamese music wanted to compose Vietnamese songs, not simply French songs with Vietnamese words, they purposely worked to make their compositions echo the tunes and rhythms of traditional folk songs. For this reason Phạm Duy calls these first modern songs dân ca mói (new folk songs) (1990, 1). Both folk songs and songs called renovated music were based on poems. Folk songs were based on folk poems of anonymous authorship called $\mathrm{ca}$ dao; some renovated songs were also based on $c a$ dao but many were based on poems by known poets, including some who were still living. Because of their origin in poems, many renovated/prewar ${ }^{12}$ songs contain traces of poetic forms, of the traditional Vietnamese form luc bát, for example (alternating lines of six and eight words) or of the famous sevenword (thất ngôn) T'ang verse form popular in Vietnam as well as China.

Though not officially banned, prewar songs were rarely heard in the North. Engaged in mobilizing the masses first to defeat the French and then the Americans and their allies, leaders of the Democratic Republic of Vietnam did not want people to listen to sentimental and romantic songs. Prewar songs were, however, heard often in the South: They were the songs that formed the backdrop against which Sơn's innovations stood out. "Entering modern music [tân nhạc] with a new spirit," says Đặng Tiến, "Trịnh Công Sơn gradually constructed a new musical language that broke the old model of renovation music [nhạc cái cách] that had emerged only twenty years earlier" (2001a, 12-13).

What did Sơn do to make his songs appear fresh and new? Văn Ngọc stresses Sơn's new approach to lyrics, which, he says, weren't restricted to the function of telling a story with a beginning and an end. "They had a life completely independent, free. They could evoke beautiful images, impressions, and brief thoughts that sometimes reached the level of surrealism; and between them sometimes there was no logical relationship at all" $(2001,27)$. Son designed his songs to make an end run around the conscious intellect to reach the heart directly. To achieve this effect he used the same techniques used by many modern poets, which is why he is so frequently called a poet, not a mere songwriter. ${ }^{13}$ These techniques include purposeful incoherence (at least at the level of logic); unusual grammar that pushes at the limits of what is acceptable; fresh diction, images and metaphors; startling word collocations; and rhyme-both true and off rhyme. All of these techniques are evident in "Diễm of the Past" (see Appendix II). Though the basic situation of the song is clear-the singer is waiting in the rain for a visit from someone he loves-the song is not a coherent narrative. "What does 'Please let the rain pass over this region' have to do with 'Let the wanderer forget he's a wanderer'?" asks Lê Hữu. "It sounds like 'The man talks chickens, the woman talks ducks'; as though a line from another song has been plugged into this one" $(2001,227)$. Son's use of unusual grammar is seen in line two: "Dài tay em mấy thuở mắt xanh xao" (Your long arms, your pale eyes). In translating this line my wife and I have left out the phrase "mấy thuở" (many times, many periods of time) because Sơn's grammar doesn't enable one to know for certain how this phrase relates to the rest of the line.

\footnotetext{
12 The distinction between "renovated music" and "prewar music" is not a clear one. As Gibbs explains, "In more recent years these songs [renovated music] have come to be called nhạc tiền chiến [prewar music] (2001a). As I suggest, however, most people consider prewar songs to be a romantic sub-category of renovated music.

${ }^{13}$ Trịnh Công Sơn's impact proves that there is nothing "mere" about songwriters, but traditionally in Vietnam poets have been more respected than musical performers.
} 
Though in "Diễm" as in many prewar songs it is raining, it is autumn, and leaves are falling, ${ }^{14}$ other words and images are not clichés. References to old temples, gravestones, and stones needing each other were not conventional in prewar songs. Probably the most famous line of this song, "In the future even stones will need each other," became famous because it contained a new and arresting image. A fourth technique, Son's use of unusual word collocations, is related to what some critics have identified as a distinguishing feature of Sơn's songs, namely his frequent use of "đối nghịch," or opposition of ideas (Cao Huy Thuần 2001b, Trần Hữu Thục 2001), a feature I will have more to say about later. In "Diễm" there is an unusual collocation in the second line in the second stanza, translated as "In the afternoon rain I sit waiting." Sơn uses the phrase "trips of rain pass" (chuyến mura qua) to describe the rain, an unusual use of chuyến (trips, flights), a word that is usually used in phrases like "plane trips," "car trips," "train trips," etc. but not to describe periods of rain (Lê Hữu 2001, 227). Some better examples occur in the second stanza of another early love song, Sơn's "Sad Love":

Love is like a burning wound on the flesh,

Love is far like the sky,

Love is near like the mist of clouds,

Love is deep like a tree's shadow,

Love shouts with joy in the sun,

Love's sadness intoxicates.

The stanza begins with the striking comparison of love to a burning wound, proof that the war is beginning to occupy the songwriter. Then come references to mist, clouds, sky, and sun, which are conventional but used by Sơn to counter not fulfill expectations, as Đặng Tiến explains: "'Love is far like the sky' makes sense, but why 'near like the mist of clouds'? . . . 'Love shouts with joy in the sun' is right, but it should be opposed to 'Love flies sadly in the rain.' Why do we get 'intoxicates' here?" (2001a, 11).

Đặng Tiến compares "Sad Love" to Đoàn Chuẩn and Từ Linh's "Send the Wind to Make the Clouds Fly," a prewar song composed in 1952 or 1953 but still popular in Vietnam in the 60s and 70s (I heard it many times in coffee houses in Huế and Đà Nẵng during the war). It begins as follows:

Send the wind to make the clouds fly,

Send the many-colored butterfly to the flower,

Send also moonlight the pale blue of a love letter,

Send them here with the autumn of the world.

According to Đặng Tiến, while the stanza from Sơn's song has fresh oppositions, these lines consist of conventional images and juxtapositions: wind-cloud, butterfly-flower, moonlight-autumn.

A final poetic technique, rhyme-both true rhyme and off rhyme-is used skillfully by Sơn to tie his compositions together. Other songwriters used rhyme but it becomes an especially important device for Sơn. Trần Hữu Thục says that in some famous Trịnh Công Sơn songs, one "sings rhyme," one doesn't "sing meaning" $(2001,56)$. I would put "Diễm" in this category. Though the fragmented meaning jars the listener, the repetition of similar sounding words at the end of lines unifies the song and has a soothing effect. Since Vietnamese spelling is quite phonetic, one can see how much rhyme is used in "Diễm" by noticing the similar spellings of the final words in the lines.

In explaining what motivated Sơn to adopt a new approach to lyrics, Đặng Tiến points to the

\footnotetext{
${ }^{14}$ Vietnamese songwriters find it hard to resist falling leaves. According to Nguyễn Trọng Tạo, fifty of the modern songs ranked in the top 100 rely on the repeated phrase lá roi (leaves fall) $(2002,13)$.
} 
vibrant and cosmopolitan intellectual climate in southern Vietnamese cities between the two Indochina Wars (2001a, 13). "People read Francoise Sagan in Saigon at the same time with Paris," Đặng Tiến says. "In the cities, especially in coffee houses, people discussed Malraux, Camus, and also Faulkner, Gorki, Husserl, Heiddegger" (14). In Huế, Sơn hung out with a highly educated group of friends which included the artists Đinh Cường and Bửu Chỉ, the philosopher and writer Hoàng Phủ Ngọc Tường, the poet Ngô Kha (who also had a law degree), and the French Professor and translator Bửu ý, head of the French Department at the Faculty of Pedagogy at Huế University (Đinh Cường 2001, 58). Sơn was clearly exposed to modernism through his own study of philosophy and through discussions with his close friends, and so when, for example, he used words that frustrated expectations, when he disdained easy meanings, when he opted for an emotional not a logical coherence, he was no doubt moved by some of the same forces that affected Apollinaire ${ }^{15}$ in France and T.S. Eliot, James Joyce, Gertrude Stein, and Ezra Pound in England and America.

Another member of Sơn's circle of friends, Thái Kim Lan, who in the early 60s was studying philosophy at the University of Huế, emphasizes the impact of Western philosophy, particularly existentialism, on the youth of Huế at this time. Concepts such as "existential angst," "being and nothingness," "the meaningless of life," and the myth of Sisyphus were, she says, hotly debated (2001, 84). Though Sơn had studied philosophy at a French lycée, according to Thái Kim Lan, he would usually sit back and listen during these discussions, but then later, to the surprise of his friends, he would compose a song and "sing philosophy." His songs, Thái Kim Lan argues, were simpler versions of the ideas they were discussing, and they helped those in her circle cut through the intellectual knots they had tied for themselves. Thái Kim Lan suggests that when in a song called "The Unexpected" Sơn sang "there is no such thing as the first death, there is no such thing as the last death," he was working on the philosophical problem of defining "beginning" and "end." In "The Words of the River's Current" he was working on the problems of "being" and "nothingness." According to Thái Kim Lan, it is his incorporation of these newer philosophical notions in his songs that distinguished his music from previous composers and made it appealing to young people (83).

Son's recently rediscovered "The Song of the Sand Crab" provides a good example of how Son's training in French philosophy influenced his composing. In this long song (truòng ca), clearly inspired by Camus' The Myth of Sisyphus, Sơn uses Vietnam's symbol of endless and futile labor, the sand crab, to present a view of life that is as bleak as Camus' though the work does suggest the possibility of salvation through love. Performed chorally in 1962 by Sơn's fellow students at the Qui Nhon School of Education, it was well-received at the time but never published or recorded until the Huế historian Nguyễn Đắc Xuân interviewed students who remembered it (Nguyễn Đắc Xuân 2003, 32-33; 39-51; see also Nguyễn Thanh Ty 2004, 15-18). Sơn's philosophical lyrics in "Song of the Sand Crab" and other works helped make his songs new but he was careful to make sure the ideas they conveyed were not too strange or foreign. "I have always liked philosophy," Sơn has written, "and so I have wanted to put philosophy into my songs." But then he specifies that what he aimed for was "a soft kind of philosophy that everyone can understand, like in a folk poem or in a lullaby that a mother sings for her child" $(2001 / 1997 a, 202) .^{16}$

But it wasn't only the words of Son's songs that made them appear fresh and appealing: his songs were more modern-sounding than songs composed by prewar composers like Đoàn Chuẩn and the early works of Văn Cao and Phạm Duy, all contemporaries of Sơn but older. What made Sơn's songs sound modern? Sơn achieved a more modern effect by not echoing, or by echoing much more faintly,

\footnotetext{
15 "When I was still in school," Sơn told Tuấn Huy, "I would take with me a book of poems by Apollinaire and murmur to myself each word of his outstanding poems and gaze dreamily out at the white clouds drifting by the window" (quoted in Tuấn Huy 2001, 31).

${ }^{16}$ For more information on Trịnh Công Sơn's "soft philosophy," including the influence of Buddhism and existentialism, see Schafer (2007).
} 
the prosody of declaimed poetry. Avoiding these echoes wasn't easy because many prewar songs carry, as I pointed out above, the traces of familiar poetic meters. Đặng Tiến, for example, argues that these lines from Đoàn Chuẩn and Từ Linh's's "Send the Clouds" echo the famous T'ang seven-word (thất ngôn) verse form popular in Vietnam as well as China:

Lá vàng từng cánh rơi từng cánh (seven words)

One by one each golden leaf

Rơi xuống âm thầm trên đất xưa (seven words)

Falls silently on old ground

In explaining how Sơn's songs differed from his predecessors, Văn Ngọc argues that "when one sings songs like "The Sadness of Autumn Passing" (1940) by Văn Cao or "Song of a Warrior's Wife" (1945) by Pham Duy, ${ }^{17}$ one can't refrain from declaiming each line, each word, as if one were singing a songstress song ( ca trù). ${ }^{18}$ As they sound in the ears, it's as if one can hear the moon lute and the singer's lute, or the drum and bamboo castanets!"19 $(2001,27)$. In contrast, Sơn's songs rarely evoke these well-known verse forms. One reason may be Sơn's education in a French lycée where unlike his friends who attended Vietnamese schools he was not made to study and memorize poems written in traditional Vietnamese and classical Sino-Vietnamese verse forms (Đặng Tiến 2001a, 11; Nguyễn Thanh Ty 2004, 101).

\section{Buddhist Themes}

In comparison to works by these older composers, Sơn's songs were fresh and new, but they were not so unusual that they sounded foreign. The mood of Sơn's music remained traditional-sad, dreamy, and romantic-and thus his songs were nicely attuned to Vietnamese expectations shaped by similarly sad lullabies and prewar songs (Văn Ngọc 2001, 27). This sad mood and the messages of many of Son's songs probably reflect the influence of his Buddhist background. Son admits to the influence of his faith and of his hometown of Huế, a very Buddhist city ringed by dozens of pagodas: "Huế and Buddhism," he writes, "deeply influenced my youthful emotions." ${ }^{20}$ Though his friend Thái Kim Lan says Sơn was dealing with Western metaphysical problems in his songs, his philosophy, as she herself ends up admitting, could probably also be considered Buddhist. "Now as I reflect I realize that . . . those new ideas were not new but were found in Buddhism" (84). ${ }^{21}$ When an interviewer suggested there was a "strong current of existentialism" in his songs, Son replied: "The supreme master of existentialism was the Buddha because he taught us that we must be mindful of each moment of our lives" (2001/1998, 211). Sơn clearly drew on both Western philosophy and Buddhist thinking. As he has said, he aimed for a simple philosophy, not a "systematized" one (2001/1997a, 202).

Though certainly not systematized, Buddhist ideas are expressed in many songs, particularly the notion of vô thuòng, or impermanence, including the idea that death is an event in a chain of cause and effect that leads to rebirth, and recognition that, as Buddha said, "Life is suffering." Impermanence is a theme of many songs: In the world of Trịnh Công Sơn nothing is forever-not youth, not a love relationship, not life. We see this theme in "Flowers of Impermanence," an uncharacteristically long

\footnotetext{
${ }^{17}$ Phạm Duy himself finds echoes of T'ang poems in Văn Cao's early songs and in his own early compositions (1993, 13).

${ }^{18}$ Ca trù, also called hát ả đào, and usually translated as "chamber music" or "songstress songs," was a diversion for learned men who went to songstresses' houses to hear them sing ancient poems or poems of their own (the men's) composition.

${ }^{19}$ These are traditional instruments used to accompany a songstress singing ca trù.

${ }^{20}$ From "Chữ tài chữ mệnh cũng là bể dâu" (The words talent and fate both lead to turmoil), an undated interview with Sơn reprinted in Nguyễn Trọng Tạo et al. 2001, 221.

${ }^{21}$ Trần Hữu Thục suggests that Sơn's new approach to lyrics (unusual word collocations and non-canonical grammar, for example) made some familiar Buddhist and Taoist notions appear fresh and new (2001, 77). This new "packaging" of traditional ideas may be why Thái Kim Lan and her circle didn't immediately detect Buddhist themes in Sơn's songs.
} 
song in which Sơn sketches the phases of a love relationship-the search for someone, the discovery of love, and then the inevitable ending. It appears also in the song "To Board" in which all living things, including the songwriter, are depicted as residing only temporarily in this world, like a boarder in a rooming house:

The bird boards on the bamboo branch,

The fish boards in a crevice of spring water.

I myself am a boarder in this world,

In one hundred years I'll return to the edge of the sky.

There is sadness in impermanence, of course, but also peace of mind if one realizes that the end of a loving relationship and of life itself is also a beginning; a departure is also always an arrival. In Sơn's songs going leads to coming and vice versa and images of a circle appear often. "The Sea Remembers," for example, begins "Tomorrow you leave / The sea remembers your name and calls you back." A later song, "A Place for Leaving and Returning," 22 is, as the title suggests, permeated by this idea of the inseparability of arriving and departing. Though commonly considered a song about death-it was sung at all Sơn's memorial concerts and played by a saxophonist as his coffin was carried to his grave-in this famous song the sadness of leaving and death are mitigated by being persistently linked to returning and rebirth (Cao Huy Thuần (2001a).

Some Vietnamese, and some Westerners who listen to his songs and read translations of his lyrics, find Sơn's songs to be "weepy," even morbid. It is an understandable reaction: most of his songs are sad; many contain references to death. Sơn has admitted being obsessed with death since an early age, perhaps because of the early death of his father $(2001 / 1998,207) .{ }^{23}$ Certainly, too, the war heightened every Vietnamese's consciousness of death. "I love someone just killed last night," Sơn sings in "Love Song of a Mad Person": "Killed by chance, killed with no appointment / killed without hate, dead as a dream." Sơn is not concerned only about the death of others: his own death is never far from his mind. He refers to it directly in some songs, for example, in "Next to a Desolate Life": "Once I dreamed I saw myself die, / Though it's true tears fell I wasn't so sad, / Suddenly I awakened and the sun was rising"; and in the "Unexpected": "Very tired I lay down with the eternal earth." In other songs he refers somewhat more obliquely to his own departure from this world - for example, in "Sand and Dust," "There'll Be a Day Like This," and "Like Words of Goodby." In Sơn's songs death and life interpenetrate each other, each giving meaning to the other. The lyrics to many of his songs suggest that he lived his life with death in mind.

In experiencing death as "an anticipatory conception" that affects one's earthly existence (Kierkegaard 1944, 150) Sơn was following the recommendations of some existentialists. In the late '50s and early '60s young intellectuals in Southern cities were fascinated by European existentialism and Sơn's close friends emphasize his intense interest in it. ${ }^{24}$ It is therefore probably not a coincidence that death appears to have been for Sơn what it was for Heidegger and Jaspers — a "boundary situation" that gives meaning to life. "I love life with the heart of someone who despairs," Sơn wrote in the introduction to a song collection $(1972,6)$. This despair or sense of desolation (tuyệt vong) which permeates many of Sơn's songs should be seen, I believe, as similar to existential "dread"—an anxiety in the face of non-being or nothingness. Paradoxically dread leads to what Heidegger called "authentic" existing, as René Muller explains:

\footnotetext{
${ }^{22}$ See Appendix II for translation.

23 "In my childhood I was frequently obsessed with death. In dreams I often saw the death of my father" (Trịnh Công Sơn 2003/1987b, 182-83).

${ }^{24}$ See Bửu Ý (2003, 18-19,89-91), Hoàng Phủ Ngọc Tường (2004, 23-25, 120), Thái Kim Lan (2001, 82-86), and Sâm Thương (2005).
} 
In Heidegger's ontology, nothingness (das Nichts), the intuition of what it means not to exist, is the basis for authentic existing. To Heidegger, only when I recognize and accept that I will lose all I know of my earthly being - even more to the point, that I am losing it at this very momentcan I come to terms with what my life is. Only then, when I am free to face my dying, am I free to live my fullest life. When I can let go of the world, I will receive the world. When I feel the Void ..., the ground of being appears under my feet. (1998, 32-33)

Though Heidegger is not a Buddhist, this is, as Muller points out, "a paradox worthy of Zen. Tathata (suchness), the true meaning of the world, or more simply, the truth about all we concounter, comes only after achieving sunyata (emptiness)" (33). An appreciation for the transitoriness of life that dread awakened in existentialists resembles the Buddhist idea of vô thuờng, or impermanance. There are many similarities between Buddhism and existentialism, as scholars have pointed out. ${ }^{25}$ In his songs Sơn blended Buddhist and existential ideas to produce an artistic whole that his listeners found new and a little strange but not too strange. By incorporating Buddhist themes in his songs, Sơn helped his listeners, most of whom were Buddhists, accept death and suffering. They found-and still find-his songs to be not morbid but consoling.

\section{Trịnh Công Sơn and the War}

The songs in Sơn's first published collection, Songs of Trịnh Công Son, released in 1965, were love songs, but we see the war intruding in some of them. "Sad Love," the last song in this collection, opens with the line "Love is like a [military] shell, a heart that is blind." In his next collection, Songs of Golden Skin (1966/67), war becomes not just a source of metaphors to talk about love but the major topic. It is these songs more than any others that created the Trịnh Công Sơn phenomenon, songs like "Lullaby of Cannons for the Night,"26 "Vietnamese Girl with Golden Skin," "A Winter's Fable," and "A Mother's Legacy." These songs are antiwar in the sense that they express sadness at the death and destruction the war is causing but they are also love songs that ask listeners to cherish love between lovers, between mothers and children, and between all people of golden skin. In these songs, to use the phrase that became a cliché in America, Sơn urges people to "Make Love not War." ${ }^{27}$

But it wasn't just the songs, it was also the public performance of the songs that sparked the Trịnh Công Sơn phenomenon. A watershed event was a performance at the Faculty of Letters of the University of Saigon in 1965. Organized by some of Son's friends, and attended by artists, intellectuals, and high school and college students, it took place on an open space behind the University. This was Sơn's first performance before a large audience and he has said that he looked upon it as an "experiment to see if he could exist in the hearts of the people" (2001/1997c, 278). He got his answer in the form of an enthusiastic response, which he later described in this way:

Carrying with me a light load of twenty songs about the native land, the dream for peace, and songs that now are called "antiwar," I tried my best to play the role of someone who wished to

\footnotetext{
${ }^{25}$ Zen is only one of school of Buddhism and there are, of course, differences between Zen and existentialism. For a discussion of similarities and differences, see Rupp (1979) and Muller (1998). In "Death, Buddhism, and Existentialism in the Songs of Trịnh Công Sơn," I argue that Sơn's "soft philosophy" is primarily Buddhist (Schafer 2007).

${ }^{26}$ See Appendix II for a translation.

${ }^{27}$ It is difficult to distinguish Sơn's antiwar songs from his songs about love and his native land. Love songs like "Diễm of the Past" and songs about the human condition assumed an antiwar quality when sung during the struggle for peace. Michiko Yoshi, a researcher associated with the University of Paris, finds 69 antiwar songs in the 136 songs Son composed from 1959 to 1972 (see Đặng Tiến 2001b, 130). For my purposes, we can consider Sơn's antiwar songs to be those songs expressing a desire for peace that are found in these collections: Ca Khúc Trịnh Công Son [1966] (Songs of Trịnh Công Sơn), Ca Khúc Da Vàng [1966/1967] (Songs of Golden Skin), Ca Khúc Da Vàng II [1968] (Songs of Golden Skin II), Kinh Việt Nam [1968] (Prayer for Vietnam), Ta Phải Thấy Mặt Trời [1969] (We Must See the Sun), and Phụ Khúc Da Vàng [1972] (More Songs of Golden Skin).
} 
convey his inner feelings to his audience. That concert had a beautiful effect on both the presenter and the audience. One song was requested eight times, and in the end the audience spontaneously began to sing along with the singer. After the concert I was "compensated" by having the privilege of sitting for an hour to sign the dittoed song sheets that were distributed for listeners. (278)

Sơn took short unauthorized leaves from his teaching job in Bảo Lộc to perform at this and other concerts in Saigon, forcing an aging teacher to cover his classes and stretching the tolerance of his school principal (Nguyễn Thanh Ty 2004, 41, 96). In the summer of 1967 Sơn's teaching career ended when he and some of his friends, also teachers in Bảo Lộc, received draft notices. Sơn, however, never reported for duty and never served in the army. He moved to Saigon and began living a rather Bohemian life. For two years after receiving his induction notice, Sơn was able to live a fairly normal life because he avoided army service by fasting for a month each year and drinking a powerful purgative called diamox that lowered his weight enough to make him fail his medical exam. But when the third year rolled around he feared his health wasn't strong enough to fast and purge himself again, and so he became a draft dodger. For several years he lived like a homeless person in some abandoned and dilapidated prefab housing behind the Faculty of Letters. Though lacking in amenities, this site had the advantage of not being checked by the police. He would sleep in a cot in the prefab housing or on the cement floor of a meeting place for young artists that had sprung up nearby. As for personal hygiene, he washed his face and brushed his teeth in one of the nearby coffee houses. ${ }^{28}$

When his songs became increasingly popular and, after the 1968 Tet Offensive, increasingly antiwar, the government of Nguyễn Văn Thiệu issued a decree banning their circulation. ${ }^{29}$ This brought Sơn increased attention from Vietnamese and foreign journalists who pursued him for interviews. "Suddenly, unavoidably," Sơn has written, "I became famous. . . . I'd escape from Saigon to Huế and a few days later I'd see people of different skin colors, from different countries, appear at my door. . . . I had to live frivolous moments in newspapers and magazines and before camera lenses until ten days before the city [Saigon] was completely liberated" (2003/1987a, 181-82). If foreign journalists could find Sơn, why couldn't the police? This remains a murky and controversial question. Some say he was protected by an air force officer named Lưu Kim Cương, a close friend of Sơn's, who may have been able to issue him some false enlistment papers (Nguyễn Thanh Ty 2004, 115). Others say that Lưu Kim Cương wasn't a powerful enough figure to help Sơn and that his key protector was Nguyễn Cao Kỳ, Prime Minister from 1965 to 1967 and Vice President until 1971. Đặng Tiến, citing several sources, says Nguyễn Cao Kỳ befriended Trịnh Công Sơn because he liked the artist and also because he was eager to garner the support of progressive intellectuals and to repair relations with the Buddhist movement in Huế, which he had helped crush in 1966 (2001b, 187).

One cannot understand the Trịnh Công Sơn phenomenon without understanding the social context in which it occurred-the cities of the South. When Sorn took the stage at the University of Saigon in 1965, he was operating in a particular rhetorical situation. Young men were being drafted and killed, artillery batteries boomed in the night, Russian-made rockets were landing in city streets, and American troops were everywhere. These events set the rhetorical tinder, and Son provided the spark. Văn Ngọc emphasizes this connection between Sơn's songs and the exigency created by the war: "The phenomenon of Trịnh Công Sơn, or more accurately the songs of Trịnh Công Sơn, can only be explained in terms of historical and social causes: Without the reality of the war and the resentment it fostered, without the atmosphere of confusion that enveloped the youth of the cities, without the sharing of feelings and emotions between singer and audience, there would never be these songs" $(2001,26)$.

\footnotetext{
${ }^{28}$ Nhật Lệ (2001/1999, 134-153), Hoàng Phủ Ngọc Tường (2001/1995, 23-27), and Nguyễn Thanh Ty (2001, 2004) describe this period of the singer's life. See also Trịnh Công Sơn's interview with Hoài Anh (2001/2000, 119-120) and his "My Draft Dodging Period" (2003/1987a, 179-182).

${ }^{29}$ According to Nguyễn Đắc Xuan $(2003,100)$, this was decree number 33, issued February 8, 1969.
} 
Of course one has to know how to seize the rhetorical moment, and Son, already moving in his love songs away from the cliches of romantic prewar songs, was sensitive and talented enough to know what this new situation demanded: a new kind of love song, a song for the suffering land and people of Vietnam, a song like "A Lullaby of Cannons for the Night," ${ }^{30}$ which contains this refrain:

Thousands of bombs rain down on the village,

Thousands of bombs rain down on the field,

And Vietnamese homes burn bright in the hamlet;

Thousands of trucks with Claymores and grenades,

Thousands of trucks enter the cities,

Carrying the remains of mothers, sisters, brothers.

As the above lines reveal, Sơn's antiwar songs differed from his earlier songs not just in subject matter but also in technique. Though he caught people's attention with illogical, metaphysical, sometimes even surreal love songs, the lyrics of Son's antiwar songs are logical and very realistic. He mentions actual battles (Battle of Pleime, Đồng Xoài) and weapons (Claymores, grenades). Compared to his love songs, which don't tell a coherent story, Sơn's antiwar songs are much more story-like and some-"Vietnamese Girl with Golden Skin," for example-tell a story with a clear beginning and end. Trần Hưu Thục suggests that when one looks at Sơn's total oeuvre, his antiwar songs stand out as atypical, their realism and clear logic distinguishing them from his love songs and songs about the human condition. They sound, he says, like "reports on the war" (2001, 63). Why did Sorn change his approach to writing lyrics? Trần Hữu Thục says it is because he wanted to send a "clear message" about the war and the necessity of peace (58).

If his message was communicated successfully, and the almost immediate popularity of his antiwar songs suggest that it was, it is no doubt because in these songs Son gave voice to the private thoughts of many, becoming, in the process, the spokesperson for an entire generation. In the many tributes to Sơn written after his death, the authors thank him for saying what they could not themselves express. "He's gone," says Bùi Bảo Trúc, in a typical tribute, "but we'll always remember him, always be in his debt, grateful to him for saying for us those things that are hardest to say"(2001, 62). "His voice," says Bửu Chỉ, "was like an invisible thread that quickly unified the private moods and destinies of individuals living in Southern cities" $(2001,30)$.

In the public presentation of his songs, Sơn was greatly aided by a talented singer named Khánh Ly, someone so important to Sơn's success that she will be described in a separate section. Sơn met Khánh Ly in 1964 when he visited the central highland city of Đà Lạt. Nineteen years old at the time, she was singing at "Night Club Đà Lạt." Though Khánh Ly was not yet well known, Sơn sensed immediately that "her singing voice was right for the songs [he] was writing" (2001/1998, 207). They struck up a partnership and soon Khánh Ly was singing only his songs and Sơn began writing songs with her voice and talents in mind. In 1967 Khánh Ly and Sơn began appearing together at universities in Saigon and Huế and other cities and at a place called "Quán Văn," or "Literature Club" in Saigon. Referring to their "phenomenal fame," Khánh Ly says "it all began at the Literature Club," a venue that she describes in this way:

The Literature Club, with a name easy to remember and so nice, sprang up in an unprotected spot in the heart of Saigon ${ }^{31} \ldots$. The roof was made of leaves and old pieces of plywood tied

\footnotetext{
${ }^{30}$ See Appendix II for a complete translation of this song.

${ }^{31}$ It was built on the foundation of a well-known colonial prison called Khám Lón (The Big Jail) and was within the grounds of the Faculty of Letters, University of Saigon (Phạm Duy 1991, 283).
} 
together; the kitchen was smaller than the one here [an apartment in Montreal] ${ }^{32}$ and was used only to make coffee. People had to find a place to sit on the cement floor amidst pieces of broken bricks and weeds. But when I was young that place for me was the most beautiful of gathering places. $(2001,57)$

Sơn was in Huế during the Tet Offensive and saw the corpses strewn in the streets and rivers, on the steps of empty homes and in the famous berry field where so many bodies were found, many of them apparently killed by National Liberation Front and North Vietnamese execution squads. Two of his songs, "Singing on the Corpses" and "A Song for the Corpses," written at this time are the most haunting of all his antiwar songs, and the most graphic. A composer who began writing dreamy songs of wet eye lashes and fleeting romances, Sơn now was writing of corpses and people driven mad by the war. In these songs, Nhật Lệ says, "it was as if he was toying with the devil and with death, but the truth was he was stunned by the pain of his country" $(2001 / 1999,146)$. The first song has a sprightly cheerful rhythm, but when you focus on the words you realize it is about people driven mad by the war, like this mother who claps over the corpse of her child:

Afternoons on the hills, singing on the corpses-

I have seen, I have seen by the garden-

A mother clutching her dead child.

A mother claps over her child's corpse,

A mother cheers for peace-

Some people clap for harmony,

Others cheer catastrophe ...

I came to Huế after the Tet Offensive and lived with a Vietnamese family within the Citadel area.

Across the street was a small store that sold music tapes and the owners would play these sad songs over and over, probably to attract buyers. As a result, they are seared on my memory, especially these lines from "A Song for the Corpses":

Which corpse is my love

Lying in that trench,

In the burning fields,

Among those potato vines?

\section{The Ethos of Trịnh Công Sơn}

Another important ingredient of a rhetorical situation is the ethos of the speaker, or in this case, singer. In other words, whether a singer can seize the rhetorical moment depends not only on the quality of the singer's message but also on the audience's perception of the character of the message deliverer. In terms of ethos, Son had two advantages. First, he was not associated with any political or religious faction. In the heavily politicized environment of South Vietnam in the 1960s and 1970s it was difficult for Vietnamese to find a voice they could trust. Newspapers were controlled by the government, officials - both military and civilian - tailored their comments to fit the current propaganda theme, and teachers were afraid to discuss political issues for fear of being accused of being Communist sympathizers. Activists on the far left, many working underground for the Communist movement, were also suspect. Son, however, kept his distance from the various political factions and his name was never linked to any of them. He had friends, like the writer Hoàng Phủ Ngọc Tường, who joined the Communist movement in 1966, and other friends like Trịnh Cung (no relation) who were in the Army of

\footnotetext{
${ }^{32}$ Khánh Ly lives in southern California but she met Sơn in Montreal in 1992. Sơn was in Montreal visiting some of his siblings who had settled there.
} 
the Republic of Vietnam. Though many of his friends were active in the Buddhist movement in Huế, Sơn never let himself become a spokesperson for the Buddhist cause. Sơn's friend Bửu Chỉ says Sơn "didn't act on behalf of any '-ism' unless it was humanism. . . In his antiwar music, he had no political intention at all: Everything was done on orders from his heart" (2001, 30). In Đặng Tiến's view the people's perception that Sơn had no ulterior political motives "was the primary reason for Trịnh Công Sơn's quick success, for his becoming a phenomenon almost overnight" (2001b, 188).

Sơn's second advantage in terms of ethos relates to his style and personality. He was of average height for a Vietnamese, frail, and wore quite large glasses, usually with horn rims. When he sang in front of large audiences, he would introduce himself and Khánh Ly very briefly and then they would sing. He spoke in the soft tones of his native Huế accent which his audience found appealing. (Some Vietnamese believe the northern accent is domineering, the southern perhaps too free and unrefined.) He was "the kind of person who inspired love not fear," says Đặng Tiến, with a voice that was "friendly, creating the illusion in many people that they were close to him, maybe not real close but certainly not distant" (2001b, 184). I met Sơn several times in Huế at his home on Nguyễn Trường Tộ Street. Journalists I knew wanted to interview him and so I'd ask students who knew him to make the arrangements. At one meeting his friend Bửu Chỉ was present. Sơn would answer questions politely and, if requested, sing a song, strumming on a scratched and battered old guitar. He always struck me to be just as his friends describe him-very modest and unassuming. Sơn's unaffected manner was important to his success because in South Vietnam in the 60s the young students who first embraced his songs formed a relatively small community. Performances were small and personal and so the ethos of the singer was an important factor.

To appreciate Sơn's advantage in terms of ethos, it is instructive to compare him to the composer Pham Duy, perhaps Sơn's closest rival in terms of fame and influence. There are several reasons why Phạm Duy could not connect with urban youth in Southern cities as effectively as Sơn. He was twenty years older, for one thing. By the mid-60s he had studied music abroad in Paris and already had an established reputation as a leading composer. In personality he was less modest-less shy about selfpromotion. And he was a northerner who joined the Việt Minh movement in the 1940s but later became disenchanted with communism and fled to the South where he became a supporter of a series of anticommunist regimes. He was a friend of the legendary CIA agent Edward Lansdale and used to attend "hootnannies" at Lansdale's private residence (Phạm Duy 1991, 218). He was also a member of the Film Center, a professor at the National School of Music, worked weekly with the government radio station, and cooperated with the U.S. Information Service on various projects. Because they recognized him as an important cultural figure, U.S. officials in Vietnam arranged for him to make several trips to the U.S. In short, he was not neutral and so some people felt he could not be trusted.

When Pham Duy's collection Ten Songs of the Heart appeared in the mid-60s, it received a mixed reaction. Some young people loved these songs, which, like Sơn's, talked of peace and reconciliation, but others reacted with some suspicion. "In his Songs of the Heart," Đặng Tiến reports, "Phạm Duy sang with great fervor 'I will sing louder than the guns next to the old rice field, ${ }^{\prime 33}$ but then he put on a black shirt and stood with groups involved in the Rural Reconstruction Program" (an unsuccessful attempt by the Saigon regime to win over people in the countryside) (2001b, 186). By the mid-60s Pham Duy had lost his ability to appeal to peace-loving students, especially those on the political left. Hoàng Phủ Ngọc Tường, a close friend of Sơn's who left Huế before Tet 1968 to join the Communist movement, writes that some students loved Pham Duy's Songs of the Heart, but left wing students considered the collection "a piece of psychological warfare designed to soften the blow of American troops" $(1995 / 1994,55)$. Pham Duy himself appears to admit that he had a political objective in writing Songs of the Heart. In his memoirs he lumps this collection in with other works "of a social

\footnotetext{
${ }^{33}$ Đặng Tiến quotes the opening line from the second song in Phạm Duy's collection, "Tiếng hát to" (A loud singing voice).
} 
service nature, songs for the Ministry of Information, the Open Arms Program, the Army, and the Rural Reconstruction Program" (1991, 218-219).

Not all Southerners, of course, appreciated Trịnh Công Sơn and his antiwar songs. His songs did, as Bửu Chỉ himself points out, have real consequences: "They got not a few young people to look at the inhumanity and cruelty of the war, and encouraged them to hide from the draft or desert. In the eyes of those who held power in the old regime, Sorn was someone who destroyed the will to fight of the troops" $(2001,31)$. This was, of course, why the Saigon regime made its futile attempts to ban his songs. That his songs had these real consequences endeared him to people like Bửu Chỉ, who painted antiwar paintings and spent time in prison for his anti-government views, but the implication that Son was in some way responsible for the Communist victory troubles others who don't share Bửu Chi's radical politics but love his songs. These friends and fans reveal their uneasiness by refusing to apply the term "antiwar" to Sơn's songs about the war. ${ }^{34}$ Phạm Duy and Trịnh Cung, who both now live in California, object to the term. Trịnh Cung, the old friend of Sơn's who was in the ARVN, argues that "antiwar" is not the proper term because "it suggests a judgement, suggests the accepting of responsibility for the South's defeat." Trịnh Cung suggests we say that Sơn's wartime works are about "the fate of the Vietnamese people" $(2001,79)$.

\section{Trịnh Công Sơn and Khánh Ly}

After 1975 many younger female singers sang Sơn's songs, including his sister, Trịnh Vĩnh Trinh, but for Vietnamese of Sơn's generation Trịnh Công Sơn will always be linked to Khánh Ly, the singer who at the Literature Club in Saigon, at performances at universities, and then on cassette tapes presented his songs to their admiring fans. Trịnh Công Sơn had a good voice and at concerts would sing half of the songs by himself, sing several duets with her, and Khánh Ly would sing the rest. But Sơn's voice wasn't as strong or as beautiful as Khánh Ly's. Văn Ngọc describes Khánh Ly's voice when she was a young singer just beginning to sing Sơn's songs:

[It] could drop very low, very deep, but also could rise very high, a strong voice, strong-winded, rich in musical quality. Khánh Ly always sang with the correct tone, rhythm, and modulation of the voice. . . . It was a voice that still had the freshness and spontaneity of a twenty-year old, but also seemed to convey sadness as well. A voice that could be flirtatious in a lovable way in romantic songs but also become angry and sad in the antiwar songs. $(2001,26)$

Like Sơn, Khánh Ly lived an unorthodox life. Her father, like Sơn's, was involved in the resistance and died after a four-year stint in prison when she was very young. Unlike Sơn she doesn't appear to have been close to her mother. She has described herself as an orphan, neglected and abandoned by her family. So she set out on her own, singing to make a living, with a little help from her friends. "I was searching," she has said of this period in her life, "living a vagabond life supported by some kind friends: one day a friend would give a little rice, the next day another would give me half a bottle of fish sauce. Poor but happy, I wasn't sad because my family didn't treat me well, renounced me" (1988, 16).

When she was eighteen Khánh Ly married and was baptized a catholic. Apparently her husband, the manager of a radio station in Đàlạt, was understanding; at least she was able to travel and perform with Sơn in Saigon and Huế (Nguyễn Thanh Ty 2004, 93). In a recent interview, Khánh Ly calls her first marriage a mistake and says that like her current husband she has lived a life of several spouses and many lovers $(2004,82)$. Both Sơn and Khánh Ly had no fathers to guide them into adulthood. Their phenomenal success may be in part a result of the freedom they had: Their fathers might have insisted

\footnotetext{
${ }^{34}$ See, for example, Trịnh Cung 2001, 79.
} 


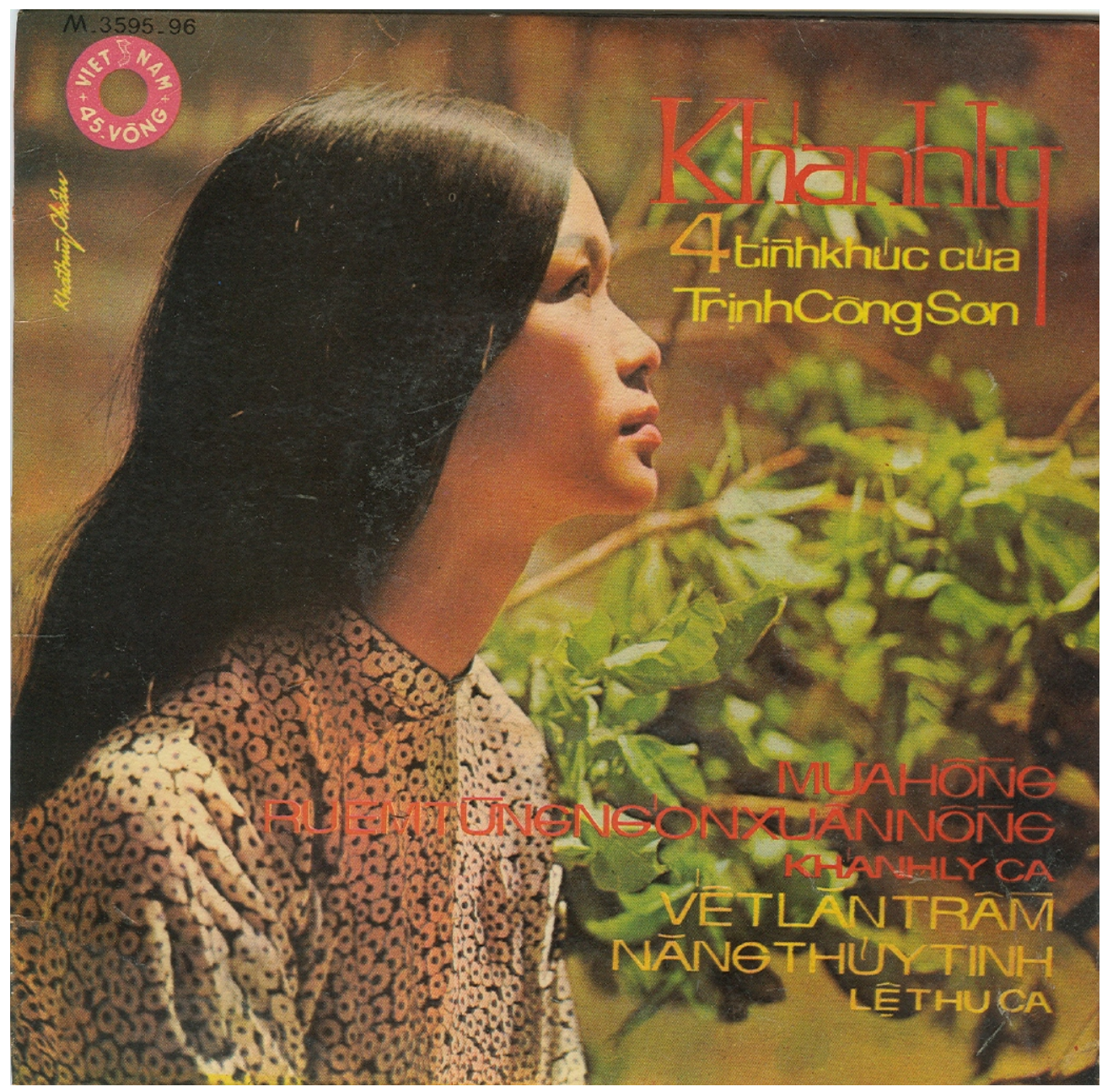

Khánh Ly on a $45 \mathrm{rpm}$ record released in 1968 on which she and another singer, Lệ Thu, sing four love songs by Trịnh Công Sơn. This was a relatively rare release. Record players were too expensive for most Vietnamese. The arrival of the cassette recorder facilitated the circulation of Sons songs. 
they lead more conventional lives.

Sơn and Khánh Ly's easy going, free relationship was part of their appeal, another contributing cause of the Trịnh Công Sơn phenomenon. They modeled a new kind of couple for young people eager to break away from rigid Confucian rules governing relations between the sexes. "They traveled together," Đặng Tiến observes, "and created the image of 'a couple,' a boy and a girl with a natural and guiltless friendship that reminded young intellectuals of Nhất Linh's fairly recent novel Đôi bạn. ${ }^{35}$ Like the couple in this novel they had their native land, love, fate, duty to the country, and all the while 'Autumn passes, winter's far away, summer brings clouds, and love's a flying bird against the sky"'36 (2001b, 185). Khánh Ly, who speaks and writes in a fairly melodramatic style, wrote movingly of her

relationship with Sơn in a 1989 article. $^{37}$ Asked about this article a year later, Sơn praised it but said that Khánh Ly's "heartfelt lines about him were for someone else, someone who has died. Khánh Ly and I were just friends. We loved each other as friends" (2001/1989, 215).

When Khánh Ly elected to come to the U.S. in 1975, and Sơn decided to stay in Vietnam, their situation symbolized for many Vietnamese the pain of separation, the sadness of exile. Around 1977-78, when the number of Vietnamese leaving by boat reached record levels, Son wrote a song called "Do You Still Remember or Have You Forgotten?" which begins:

Do you still remember or have you forgotten

Saigon where the rain stops suddenly and it's sunny again,

Old streets that know the names of passers by,

Street lights on each sleepless night,

Mornings under the green dome of tamarind leaves?

Do you still remember or have you forgotten

The neighbors that you often visited no matter the season,

The street that lies and listens for rain or for sun?

You are gone but this place is the same,

Above the small streets the leaves are still green.

Sơn and Khánh Ly may have been just very close friends, not lovers, but many Vietnamese believe he wrote this song for her. ${ }^{38}$

\section{The Cassette Recorder}

According to Gibbs' definition, in the West "popular music" is an urban music, usually marketbased, that is distributed by the mass media (Gibbs 1998b). Trịnh Công Sơn was a "popular" singer in the sense that his music was modern and urban, but it wasn't-at least till the mid 60s-really "marketbased," nor was it "distributed by the mass media." When the Trịnh Công Sơn phenomenon began, his songs were distributed on dittoed song sheets that Sơn and Khánh Ly passed out at concerts. Other students would copy them into their student notebooks. Later more professionally printed collections appeared each one containing the words and music to around a dozen songs. When the war escalated in 1964-65, American troops poured in and with them came consumer goods, part of the U.S. plan to boost South Vietnam's economy. Japanese Honda motorcycles and Akai and Sony tape recorders soon

\footnotetext{
${ }^{35}$ In Đôi bạn (Two Friends), published in 1936, a revolutionary named Dũng is in love with Loan, a modern woman who along with Dũng struggles against the rigidities of a feudalistic, Confucian society.

${ }^{36}$ Đặng Tiến quotes lines from Sơn's song "Calling the Names of the Four Seasons."

${ }^{37}$ This article is mentioned by Lữ Quỳnh in an interview with Sơn $(2001 / 1989,214)$.

${ }^{38}$ According to Cổ Ngư, many southerners appreciated this song because it was the first song after April 30, 1975, to refer to their beloved largest city as Saigon not Ho Chi Minh City (2001, 9-10). Circulation of this song was forbidden as I explain in the section "Adapting to a New Regime."
} 
became readily available. The first tape recorders to be used in Vietnam were the large reel-to-reel variety, which the Vietnamese called (and still call) Akai after the brand name. These were cumbersome and expensive but were soon replaced by the much more convenient and considerably cheaper cassette tape recorders.

These developments led to this somewhat paradoxical situation: The same American escalation of the war that provoked Trịnh Công Sơn to write antiwar songs also provided him with a means for their distribution and thereby helped to make him a "popular" singer in the American sense of this term. Phonograph records were available since French colonial times but were never widely distributed in Vietnam, probably because they require sophisticated technology to produce and because both the records and the phonograph to play them on were expensive-beyond the means of all but the richest Vietnamese consumers. Tape recorders, especially the cassette type, however, could be purchased by the middle class. Cassette tapes, which are easily duplicated, became an important means of distributing his songs, especially after the government banned them.

In principal, to circulate songs in South Vietnam one had to get written permission from the Office for Coordination of Art Works (Sở Phối Hợp Nghệ Thuật), a division of the Ministry of Information (Bộ Thông Tin). ${ }^{39}$ After this ministry officially banned his songs and tapes by directive number 33 issued February 8, 1969 (Nguyễn Đắc Xuân 2003, 100), Sơn would print his songs and duplicate his tapes illegally. I have eleven Trịnh Công Sơn song books and half a dozen tapes that I purchased in Vietnam between 1969 and 1973 and only "Outpourings of the Heart" (Tự tình khúc), a printed collection of politically safe lullabies and love songs published in 1972, has a "censorship permission number" (số giấy phép kiểm duyệt). Publishing illegally wasn't easy, as Sơn has explained. Police would come to his printer's premises to confiscate books and tapes so he had to find four different printer/distributors: if the police confiscated his collections at one printer, he kept producing them at another (2003/1987a, 181). The government's ban made it difficult for Son to sell his music and ensured it would never he heard on the radio but it could not prevent the circulation of cassette tapes.

The close association of Trịnh Công Sơn's antiwar songs with the cassette tape recorder is supported by comments by Đỗ Ngọc Yến in a 1987 article called "Phạm Duy's Songs of the Heart and the Folk Song Movement." I argued above that though Phạm Duy's Ten Songs of the Heart (1965) resembled Son's songs in some ways-they had Buddhist themes, promoted reconciliation, etc.-they were not as popular with young people because Pham Duy's life history and personal style endowed him with a very different persona or ethos. This is certainly one reason why many embraced Sơn's songs more enthusiastically. Đỗ Ngọc Yến, a political conservative who dislikes Trịnh Công Sơn's antiwar songs, suggests another:

One of the important musical movements that followed "Songs of the Heart" was antiwar music, Trịnh Công Sơn music. It was very popular at that time thanks to the cassette. You never found "Songs of the Heart" on a cassette because when "Songs of the Heart" appeared the cassette phenomenon had not yet arrived; there were just the large and cumbersome reel-to-reel machines. Even now [1987] if you want to listen to antiwar music you can go to "Tú Quỳnh" or "Thanh Lan" on Bolsa Street [stores in Little Saigon, Orange County, CA], buy a cassette, and listen to it. But if you want to listen to "Songs of the Heart," forget it. $(1987,125)$

Phạm Duy acknowledges the role of the cassette recorder in Trịnh Công Sơn's success in his capsule summary of the Trịnh Công Sơn phenomenon: "Trịnh Công Sơn' songs appeared, then they were propelled by the Khánh Ly rocket into the tea houses, then by cassette, and in a very short time they won

\footnotetext{
${ }^{39}$ Sâm Thưong, via an e-mail dated May 9, 2004, has provided me with information on how Sơn managed to circulate his songs.
} 
over everyone who heard them" $(1991,285)$.

\section{Adapting to a New Regime}

Robert Shaplen, the well-known American war correspondent, visited Trịnh Công Sơn a few days before the fall of Saigon. Pandemonium was beginning to set in. Americans already had been told where to go to be evacuated. Shaplen asked Sơn if he intended to remain. "Yes, I will stay here-we are all Vietnamese," he replied. "But if the Communists don't offer me inspiration, I won't write" $(1985,92)$. Shortly after Communist troops entered Saigon on April 30, 1975, Son accepted an invitation from the new authorities to sing "Join Hands in a Great Circle" on the Saigon radio. In this song, which Sơn had written in the late $60 \mathrm{~s}$, the singer imagines people joining hands and forming a circle that encompasses the entire country of Vietnam. For some Vietnamese this was a traitorous act. When he returned to Huế after the Communist takeover, some residents who didn't like the new regime criticized him for adapting too quickly to the new reality (Nguyễn Duy 2001, 62).

Though they invited him to sing after their victory, Communist authorities were not certain how to deal with Trịnh Công Sơn. They are still struggling to define their position vis-à-vis his work, particularly his antiwar songs. In Fragments of the Present: Searching for Modernity in Vietnam's South, Philip Taylor surveys changes in state policy from 1975 to the late 1990s and relates them to different notions of modernity (2001). Taylor is interested in how Communist authorities regarded the culture of South Vietnam, the old Republic of Vietnam, after their victory in 1975. Taylor's survey is useful because it shows how policy changed, each change creating a different climate for artistic production. Because Trịnh Công Sơn's ability to adjust to the policies of the new regime is another reason for the Trịnh Công Sơn phenomenon, it is useful to look at Taylor's scheme to get an overview of the challenges Trịnh Công Sơn faced after the war ended.

Simplifying Taylor's survey somewhat we can speak of three major phases. In the first phase (1975 to the early 80s) Communist leaders set out to eradicate all "cultural vestiges of neo-colonialism" (tàn du văn hóa thực dân mới) and build socialism in the former Republic of Vietnam (32). During this phase modernity (văn minh, hiện đại) was associated with socialist societies in the U.S.S.R. and the Democratic Republic of Vietnam. Mass mobilization and collective effort, viewed as keys to the recent military victory, were seen as the way to solve post-war problems. The street markets in Saigon and other Southern cities and weepy love songs, called "yellow music" (nhac vàng), were thought to be corrupting influences on revolutionary soldiers and cadre. Both were viewed as subversive weapons of the neo-colonialists, not as signifiers of modernity. The second phase (mid-1980s to the early 1990s) began when Communist Party leaders realized that mass mobilization and collectivization were not increasing agricultural production or promoting economic growth. To revitalize the economy these leaders launched đổi mói i, or renovation, in 1986 and moved the country toward a market economy. Aspects of Southern (especially Nam Bộ) culture previously viewed with suspicion — a passion for commodity relations and an individualist mentality, for example — began to be seen in a different light, as elements of modernity.

In the third phase (early to late 1990s) modernity, Taylor argues, was "reinvented as threat" (119). Hanoi-based leaders stopped praising the South's engagement with the outside world, fearing that it was opening up the country to subversive influences. Some southern intellectuals were also concerned. Renovation, they argued, was bringing with it a host of social evils - corruption, depraved music, and foreign videos, for example - that were destroying traditional southern culture. Calls from leaders to eradicate yellow music and other vestiges of neo-imperialism were heard again, just as in phase one, but in this third phase, Taylor argues, the analyses were more complex: "The simplicity of conspiracy theories gave way to awareness of more diffuse factors and the language of unintended consequences" (131). Some commentators pointed out that Vietnam was not the only country fighting the influence of 
foreign cultures. Taylor mentions encountering "state-employed intellectuals and cadres" who praised France's determination in the GATT convention of 1993 to protect its film industry from "Hollywood incursions" (132).

In all three phases, but particularly, in phase one, the Communist authorities were worried about the pernicious effect of what they called nhac vàng (yellow music). ${ }^{40}$ Therefore in deciding how to treat Trịnh Công Sơn one of the questions that they had to consider was whether his music fit into this category. The term has an interesting history. It was borrowed from China where beginning at least as early as the 1940s yellow music (huangse yinyue; hoàng sắc âm nhạc in Sino-Vietnamese) referred to a hybrid of jazz and Chinese folk melody that was made famous by a composer named Li Jinhui. Chinese Communist authorities linked yellow music to sing-song girls, prostitution and depravity and banned it outright from the Chinese mainland in the 1950s and 1960s (Jones 2001). According to Tô Vũ, the term yellow music began to be used in the DRV in the mid-50s to describe music that was thought to contain "ideas that were not good, not healthy, that required criticism" $(1976,44)$. It has continued to be used by Communist officials in Vietnam to describe songs that they find too weepy, soft, and sentimentallove songs, for example, that "lead people into a state of suffering over love, the opposite of the ideal happiness that people expect to find in it" (45). For Communist revolutionaries the term "yellow music" always has a pejorative meaning. Some music sellers in Saigon during the war, however, used it as a positive term, stamping "yellow music" on their tape and records to identify the sentimental music they were peddling (43).

Apparently some in the revolutionary movement thought Trịnh Công Sơn's songs were yellow music but his friends in the movement argued otherwise. "Right after liberation," Sơn's friend Hoàng Phủ Ngọc Tường told Giao Vy in a 2002 interview, "students put up a banner at the School of Pedagogy in Huế that called for the overthrow of yellow music [đả đảo nhạc vàng]." Considering this banner an attack on his friend Trịnh Công Sơn, Huế's most famous composer, Hoàng Phủ Ngọc Tường acted quickly: "I searched for the person responsible in order to get it removed immediately. In the atmosphere after April 30, 1975, there were a lot of individual opinions about Son, but we artists were determined to protect him" (Giao Vy 2002, 32). Nguyễn Duy, a poet and war reporter from the North, also became a protector and friend of Trịnh Công Sơn after 1975. One way he protected him was by carefully distinguishing his songs from yellow music. He wrote an article in which he admits he secretly listened to Khánh Ly singing Sơn's "reactionary" songs, including "Diễm of the Past" and "Like a Flying Heron," on a Saigon radio station while accompanying the 308th Division in the Route 9-Southern Laos operation $^{41}$ in 1971:

My first impression was that these soft songs of intense love did not belong to the category of sickly, moaning, complaining songs that at that time people were calling "yellow music." Yes, there was sadness there, and pain, even gut-wrenching agony, but there was something healthy sprouting there too. It seems it was beauty. Beauty in the rhythm. Beauty in the words, both in their form and poetic quality. Dim, vague, hard to get a fix on meaning, but clearly beautiful, oh so beautiful, and also a little haunting. $(1987,59)$

For agencies in charge of culture and information, however, it seems that the major problem was not Sơn's sad love songs. Nguyễn Đắc Xuân, an historian from Huế and a Communist Party member, describes a meeting held in Huế soon after liberation to discuss this question: "Do Trịnh Công Sơn's

\footnotetext{
${ }^{40}$ The Vietnamese word vàng means "gold" (the color and the precious metal) and "yellow." It can have a positive connotation as in the title of Trịnh Công Sơn's most famous song collection, Ca Khúc Da Vàng (Songs of Golden Skin), or a negative connotation as in bệnh vàng da (jaundice). For promoters of nhạc vàng, "vàng" has a positive connotation; for those who dislike this kind of music, a negative one. I translate vàng as "gold" or "golden" when it refers to the color of the skin of the Vietnamese people.

${ }^{41}$ The ARVN and its American advisors called this operation, a disastrous defeat for the Saigon regime, Lam Sơn 719.
} 
contributions outweigh his offenses?" Those attending were local officials in charge of education and culture and also important writers, some of whom, such as Hoàng Phủ Ngọc Tường, were old friends of Sơn's who had just returned from the war zone. According to Nguyễn Đắc Xuân, it was Sơn's early antiwar songs, primarily his collection Songs of Golden Skin, that posed the problem. Some officials disliked the fact that in these songs Sơn opposed war generally (phản chiến một cách chung chung), failing to distinguish "a war of invasion from a war to liberate the people" (Nguyễn Đắc Xuân 2003, 99). They particularly disliked Sơn's reference to "twenty years of civil war," which suggests there was no invasion, in a song called "A Mother's Legacy." Another offense was Sơn's writing of a song about the death of Lư Kim Cương, the air force officer who was a close friend of Sơn's, the man, who, according to some accounts, used his influence to keep Son out of the Saigon army. In "For Someone Who Has Fallen," Sơn mourns the death of his friend who was killed in an artillery attack on the Tân Sơn Nhất Airport during the 1968 Tet Offensive. Obviously Communist officials were not enthusiastic about a song fondly remembering an officer who fought for the Saigon regime.

On the plus side Sơn's supporters at this meeting pointed out that Sorn's antiwar songs had persuaded many Republican soldiers to desert, which is why the Saigon government banned them. Hoàng Phủ Ngọc Tường explained that Sơn had written "For Someone Who Has Fallen" not because Lưu Kim Cương was an officer in the Saigon forces but because he was a friend who had helped him avoid military service. At this meeting Sơn's supporters also called attention to Son's relationship to the poet Ngô Kha who, when he became an officer in the Saigon army, "provided the [revolutionary] movement with a great deal of secret internal information" (Nguyễn Đắc Xuân 2003, 77). Arrested several times by the Saigon regime, he is believed to have died in captivity in 1973. In 1983 he was posthumously given the title "Revolutionary Martyr" (Liệt sĩ) by the Socialist Republic of Vietnam (79).

Sơn's supporters argued at this meeting that Ngô Kha influenced Sơn's political views and composing style and that these changes are clearly visible in songs he wrote beginning at the end of 1968, songs appearing in Prayer for Vietnam and We Must See the Sun, songs like "Huế Saigon Hanoi" which contains these lines:

A million brothers and sisters in all regions rise up and revolt, The time has come for young people to join together,

To take pioneering steps, From the Center, the South, and the North

People wait to light torches hailing freedom.

Apparently Nguyễn Đắc Xuân and other supporters of Trịnh Công Sơn were able to construct a persuasive narrative of the singer's transformation from a neutralist and humanist who opposed all war to a committed advocate of the revolutionary struggle. "The conclusion of the meeting," Nguyễn Đắc Xuân writes, "was that before he formed connections to the Revolution the musician Trịnh Công Sơn was generally patriotic. After he formed these connections with the revolutionary structure (which included Ngô Kha), he stood, in the final stage of the patriotic struggle, completely with the Revolution" (100-101).

In evaluating both Sơn's mood and the degree of creative freedom he was allowed after 1975 friends who reside in Vietnam paint a rosier picture than overseas Vietnamese. The overseas Vietnamese press reported that Son had to spend time in a reeducation camp or to go to a new economic zone in Khe Sanh, but it seems clear that what he had to do, particularly during what I have called Phase I of the post-war period, was to participate in "productive labor for self-sufficiency" (đi sản xuất tư túc) not "labor for reeducation" (đi lao động cải tạo). Everyone, including party members, had to participate in these projects (Nguyễn Đắc Xuân 2003, 106-108). After he was cleared by the local agencies in Huế and invited to join the Writers and Artists Association of Bình Trị Thiên (the provinces of Quảng bình, 
Quảng Trị, Thừa Thiên), Sơn participated in mass mobilization projects and also in cultural activities. In one interview Sơn talks about planting and harvesting rice, manioc and potatoes in Cồn Thiện near the $17^{\text {th }}$ parallel, an area that Sơn says was "interlaced" (chằng chịt) with mines $(2001 / 1993,19)$. In an article that appeared in a regional journal, Sơn writes enthusiastically about his participation in a project to dig an irrigation ditch near the Thạch Hãn River in Quảng Trị Province in early March, 1978. He describes the glowing, healthy faces of the workers as they moved earth with primitive tools (2003/1978, 168).

Though in pre-1975 songs like "Rise Up Vietnam" and "Rebuild People, Rebuild Homes" Sơn had dreamed of rebuilding the country when peace finally came, his prose account of this irrigation project appears overwrought, especially given what we know of the terrible economic situation of the country in 1978. Both he and the workers he describes appear too happy to be believed. In assessing Sơn's state of mind during this difficult period after 1975, one should not rely too much on his published writing. Writers and artists were expected to make their works conform to the current party line. In the late 70s when government leaders were still pushing collective projects that mobilized the masses, writers and artists had to support them. Son tried to cooperate by writing songs encouraging production, turning out forgettable songs like "Carrying Vegetables to Market" and "Tractor on the State-run Farm." After hearing these songs, Trần Tuyết Hoa, a close friend, told him he should return to writing songs about love between people and let others write songs glorifying socialist labor (2006). In the late '70s the authorities were pushing a literalism and sunny optimism that Sơn was constitutionally unable to produce. "Knowing his 'new music' was not good," says Nguyễn Đắc Xuân, Sơn "served socialist art by writing essays" (2003, 104).

It would be wrong, however, to suggest that Sơn was always an unwilling participant in the cultural life of his country after 1975. The poet Vĩnh Nguyên, like Sơn a member of the Association of Writers of Bình Trị Thiên, mentions that on trips to visit work projects in central Vietnam Sơn sang enthusiastically to appreciative audiences (2001, 29-38). Son himself claims that he saw advantages in the new rhetorical situation in which he found himself: "I have a wider audience now-workers and peasants as well as students-and I travel about and sing for them, too," Sơn told Shaplen when the American correspondent returned to Vietnam in 1985 to cover the tenth anniversary of the Communist victory. "Vietnam has not lost its taste for song and melody," Trịnh Công Sơn continued. "In fact, there is a mass audience today, and there wasn't before" (quoted in Shaplen 1985, 92). Son assumed various positions in government organizations designed both to promote and control artistic production. After moving to Ho Chi Minh City in 1979, for example, he served on the executive committee for the Metropolitan Association of Music and for the United Metropolitan Association of Culture and Art.

In 1977 Sơn visited a state farm near the Cambodian border where he met and sang with young members of a youth assault team [Thanh Niên Xung Phong]. Six months after his visit he learned that twenty young women belonging to this team had been captured and beheaded by Khmer troops loyal to the murderous Pol Pot. Son has explained that he wrote a song called "From a State Farm You Went to the Border" as "a private remembrance for these young friends" (2001/n.d.[a], 188). Son' new friend from the North, Nguyễn Duy, liked this song, offering it as evidence that Sơn had turned over a new leaf, abandoned his "Zen current" (as in "A Place for Leaving and Returning") and embraced the reality of life $(2001 / 1987,64)$. But Nguyễn Hoàng Văn, an exile writer, calls this song propagandistic and faults Sơn for depicting "hard labor [at the state farm] as if it were like going to a festival or to a meeting with one's lover" $(2001,56)$. Another exile, Trần Hữu Thục, says songs like "From a State Farm" were written "in order to survive" (với mục đích sống còn) $(2001,71)$. Nothing wrong in that, Trần Hữu Thục says, we all want to survive, but he suggests these songs weren't the kind of songs that Son truly wanted to write, which is why he left them out of a collection of songs published in $1998 .^{42}$ In an interesting

\footnotetext{
${ }^{42}$ This is the collection mentioned in the next paragraph.
} 
analysis of Sơn's use of pronouns in his lyrics, Trần Hữu Thục says that only in these "survival" songs and in some songs from the 60s and 70s does "I" (tôi) become "we" (ta). The earlier songs he has in mind are songs like "Huế Saigon Hanoi," which I quoted from earlier, and other songs from the collections We Must See the Sun and Prayer for Vietnam, songs that, as we have seen, Son's supporters after 1975 offered as support for their claim that by the end of 1968 Son's heart was with the revolution.

Songs like "Huế Saigon Hanoi" were composed to be sung in groups. Trần Hữu Thục calls them "movement music" and argues that "they clearly are influenced by the martial music [nhạc chiến đấu] of the North $(2002,65)$. Those of Sơn's generation who matured when the country was divided at the seventeenth parallel responded enthusiastically to the cry for unity voiced in these "movement" songs, but Trần Hữu Thục feels that the real Trịnh Công Sơn is not revealed in them, or in his "survival" songs-in any songs written at least partly to mobilize the masses. Sơn didn't include them in his collection Trịnh Công Sơn: Tuyển tập nhũng bài ca không năm tháng (Trịnh Công Sơn: Selected Songs not Tied to Years and Months) because, he says, Sơn felt these songs were tied to years and months.

Thái Kim Lan, Sơn's old friend with whom he discussed philosophy in the early 60s, worried about him when she returned to Huế in 1977, her first trip home since leaving Vietnam twelve years before. Thái Kim Lan met Trịnh Công Sơn on this trip and heard him sing a song called "Each Day I Choose a Piece of Happiness" soon after he wrote it. Despite its rather upbeat title, she felt it revealed the songwriter having to work awfully hard to be happy-showed him trying to make do with little freedoms because larger ones were denied him. "Each Day" begins

Each day I choose a piece of happiness,

Choose some flowers and some smiles;

I pick up the wind and invite you to take it,

So your eyes will smile like a leaf in flight.

Here is the refrain:

And in this way I live happily each day, and in this way I enter life, I love this life with all my heart.

"That little piece of happiness," Thái Kim Lan says, "like a tear too dry to fall, broke my heart"(2001, 102). After Sơn moved to Saigon in 1979, he sang "Each Day" on television, the first song the new regime allowed him to perform using that medium. Not surprisingly, given the tenseness of the times, it was criticized by people both in and outside the country. In-country newspapers rejected it as bourgeois fluff inappropriate for a country engaged in productive labor and a border dispute with the Khmer Rouge and their Chinese "expansionist" allies. Overseas Vietnamese-recently exiled from their homeland, many with relatives in re-education camps or fleeing the country in small boats-wondered what happiness Sơn was singing about (Cổ Ngư 2001, 9).

Of all his friends, the artist Trịnh Cung (no relation), who lives in the U. S., presents the most dismal picture of Son's life after 1975, calling it "a small tragedy in the larger tragedy of the country" $(2001,81)$. He says Sơn was frustrated by the petty political objections to his songs which, along with other problems, drove him deeper into alcoholism. Trịnh Cung was in the ARVN and he painted this bleak picture of Son's post-75 life in a talk he gave at a memorial service in Little Saigon (Orange County). He may exaggerate, but others and Sơn himself confirm that he was bothered by some ridiculous objections to the words of several songs he wrote after 1975, objections that reflect a sensitivity bordering on paranoia on the part of the authorities. 
When Sơn went to Ho Chi Minh City in 1979, the authorities there were pushing a movement called "Political Songs" (Ca Khúc Chính Trị), songs to encourage the building of socialism. ${ }^{43}$ While still in Huế, Sơn had contributed to this movement by sending his songs "Carrying Vegetables to Market" and "The Tractor at the State-farm" for another singer to sing at a concert organized by the Association of Patriotic Intellectuals. The general secretary of this association, Huỳnh Kim Báu, was a Party member but not a hardliner and so his association attracted many intellectuals associated with the former regime, some of them, like the writer Thế Uyên, recently released from reducation camps. From 1979 to 1981 this association sponsored a series of concerts featuring Trịnh Công Sơn and other singers, a group that came to be called "The New Composers Group" (Nhóm Sáng Tác Mới). Knowing that people were tired of political songs, this group wrote and performed songs that resembled those sung in the South before 1975. Concerts by this group eventually convinced some key people, including Võ Văn Kiệt, then Secretary of the Party Committee for Ho Chi Minh City, that the government had nothing to fear from this group and their songs.

But it wasn't easy. To test the political winds, the Association organized an in-house concert and invited some members of the Fatherland Front. Sơn sang "Like a Green Marble," "To Board," and "Each Day I Choose a Piece of Happiness." When Sơn finished singing a member of the Fatherland Front rose and criticized "Like a Green Marble," arguing that it lacked a proper position (không có lập truòng). In this song, Sơn compares the planet earth to a green marble: It ends with these lines: "Like a green marble / The earth turns round / Without thinking together we choose / This place to be our common home." The Fatherland Front member faulted Sơn for not distinguishing friends and enemies. It was wrong, he said, to suggest that the whole world was as small as a marble because then anywhere could be one's native land. If you go to America would you make America your native land, he wanted to know. Son stood up and said: "Ladies and gentlemen, I think the war has ended. I want to speak of peace for all humankind." Luckily wiser heads than this critic from the Fatherland Front prevailed and Trịnh Công Sơn and the "The New Composers Group" began to sing to enthusiastic audiences.

But the authorities continued to object to certain songs. Thanh Hải, a singer who helped popularize songs Son wrote around 1980, songs like "Do You Still Remember or Have You Forgotten" and "Evening in My Native Land," reports that the authorities objected to the line "You are gone but this place [Saigon] is still the same" in the former song. They thought, says Thanh Hải, that Son was implying that Saigon hadn't been improved since 1975 (2001, 38). After Khánh Ly sang this song for a Vietnamese language program on Voice of America, authorities forbade its dissemination (Cổ Ngư $2001,9) .{ }^{44}$ The authorities also objected strongly to a song Sơn wrote in 1984 called "Remembering Autumn in Hanoi," banning its circulation for two years. Written after Son spent two-months in Hanoi in 1984, the song contains beautiful images of the ancient capital in autumn. Trịnh Cung says authorities objected to Sơn's singing about autumn because of its association with the Autumn Revolution of 1945; and they questioned the line "Each small street will answer me" and the coda "Autumn in Hanoi, I remember one person to remember everyone." Why, the authorities wanted to know, do the streets have to answer? And is Khánh Ly (considered the pride of reactionary elements in the U.S.) the "one person" that you are remembering? (Trịnh Cung 2001, 82). "Really sad," Sơn said of these objections to his paean to Hanoi (2001/n.d. [c], 219).

"Autumn in Hanoi" was written in 1985. The fact that it was banned indicates that Trịnh Công

\footnotetext{
${ }^{43}$ Trần Tuyết Hoa (2006) tells the story of Sơn's participation in concerts sanctioned by the Association of Patriotic Intellectuals. This and the following paragraph are based primarily on her account. See also Nguyễn Văn Lực (2006) and Bửu Ý $(2003,31)$.

${ }^{44}$ Party member Nguyễn Đắc Xuân, however, calls this a "revolutionary song" because when economic conditions were so bad that, as one villager told him, "Even the light poles would leave the country if they could," Sorn composed and sang this song that affirmed the beauty of life in the homeland (2003, 116-119).
} 
Sơn's works were carefully screened even as Phase I was giving way to Phase II. Sơn must have found it difficult to stay true to his own artistic vision without provoking the censors. In his 1985 meeting with Shaplen, he emphasizes the value of change, but his words appear to be phrased in a way to please those regulating cultural production. When Shaplen asks him whether he finds less sadness in Vietnam now (in 1985), Sơn says: "There is no sadness the way there was. If there is any, it is a private sadness of pathological people-people who hug it in their hearts and don't accept the fact that society has changed. They haven't changed, and they blame society. They don't share the common cause" (qtd. in Shaplen $1985,92)$. In these comments Sơn sounds like a good student of socialist realism, which encourages optimistic works and discourages the expression of purely private (riêng) thoughts detached from some common (chung) purpose. He was, however, speaking to a foreign journalist a year before đổi mói $i$, Vietnam's glasnost, came to Vietnam, and Party Secretary Nguyễn Văn Linh officially "loosened the strings" on journalists, artists and writers. Probably Sơn's comments were shaped by his awareness of the party line. (Surely he isn't saying that the sadness he expressed in songs like "Diễm of the Past" and "A Place for Leaving and Returning" is pathological!)

That Trịnh Công Sơn in his heart had never repudiated songs like "Diễm of the Past" is made clear by his actions at a concert that Taylor describes in Fragments of the Present. The concert, which took place in Ho Chi Minh City in 1985, was organized to commemorate the composer Văn Cao and several of this composer's prewar songs were played. "During the concert," writes Taylor, "popular southern musician Trịnh Công Sơn sneaked in a rendition of his own 1960s hit Diem Xua [Diễm of the Past], which had not been played in an authorized context for ten years. His audacity reportedly earned him a prolonged, emotional ovation from the audience" (154). This concert occurred at the beginning of Phase II when authorities, caught up in plans to move toward a market economy, were worrying less about the harmful effects of yellow music. According to Taylor when other singers began to perform pre-1975 music, the government released a list of 36 acceptable songs composed before liberation. By 1991, as Phase II was ending, the list had grown to 219, including around 50 by Trịnh Công Sơn, still a very small percentage of the approximately 600 songs he composed before 1975 . These numbers were provided by Lê Nam, the manager of the tape and record/CD section of the Ho Chi Minh City Office of Performing Arts, a division of the Ministry of Culture and Information, in a 2003 interview with reporters (Thu Hà 2003). He explains how the list got expanded. Pressured by the public and by composers of pre-1975 music to approve more songs, his office suggested to the Ministry of Culture and Information in Hanoi that a delegation be sent to Ho Chi Minh City to discuss the issue. This delegation met with the police (co quan an ninh) and local Ministry officials, and together they composed the list of acceptable pre-1975 songs.

In Phase III, which corresponds roughly to the last ten years of Trịnh Công Sơn's life, demands from the public to hear more pre-1975 songs by Trịnh Công Sơn and other composers continued and gradually the Office of Performing Arts added works to the approved list. In that interview mentioned above, Lê Nam said there were around 250 Trịnh Công Sơn songs-some composed before 1975, some after-legally circulating at the present time (in 2003). When a reporter asked him why "many works by Trịnh Công Sơn composed before 1975 are still waiting approval," he replied: "In managing cultural works, the Office of Performing Arts bases its decisions on the political views of the author. That's why besides works by Trịnh Công Sơn some works by others, Phạm Duy and Hoàng Thi Thơ, for example, have not been permitted to circulate." When a reporter asked whether only date of composition, not content, provoked censorship, Lê Nam answered in this way: "Not every song by Trịnh Công Sơn that may be circulating now has a positive meaning at this time, especially those songs in the collection Songs of Golden Skin. The antiwar content is raised in a very general way, with no distinction made between a non-righteous [phi nghĩa] and righteous [chính nghĩa] war. The collection Songs of Golden Skin could have been suitable for the situation in the South [Miền Nam] during the years and months before 1975 but not appropriate for the current situation" (Thu Hà 2003). 
Some artists would have been worn down by continual objections to their works, particularly if they were, as was true in Sơn's case, almost always based on political not artistic grounds. Sơn had to be courageous, tactful, and patient to keep his voice alive. In understanding how he survived emotionally and artistically it is important to realize that he was a kind, gentle person, the product of a father-less but loving family. He was always surrounded by a group of friends. After 1975 he formed new friendships, some of them with singers and artists associated with the new regime, people whose background and artistic training were very different from his. Because he never married, he had time for his friends, and what loyal, loving friends they were! Since his death many people, both men and women, people of various political persuasions, have written very moving tributes to him. Of course the tribute genre encourages exaggeration, but after reading these tributes one begins to think that Son's greatest achievement was not the songs he wrote but the friends he made-and kept-despite political winds swirling overhead. "To love people is also to love songs," he once said, "because within a song lies a human soul" (2001/n.d. [b], 162). Sơn loved songs and people with equal passion. Understanding Sơn's personality is important because it seems possible that what some people regard as political expediency was simply the outpouring of a generous heart. "What's the point of getting angry, blaming people," Son has written, "when life will wash away the bruises on our souls if our hearts are kind and gentle?" (2001/1997a, 201).

Son's kind and unassuming "ethos" referred to earlier was effective because it was who he was; it was not a crafted image. In "Each Day I Choose a Piece of Happiness," Trịnh Công Sơn sings

Each day I choose to sit very quietly,

Look closely at my native land,

Think over my life;

I realize then why I live:

Because my country needs a good heart.

And in another song called "Let the Wind Blow It Away" he sings

To live this life

You need a good heart,

To do what do you know?

To let the wind blow it away.

In other words for Trịnh Công Sơn a good heart was not a means to something else, it was an end in itself, or more accurately, it was both means and end. "A gentle generosity and boundless tolerance," says Hoàng Phủ Ngọc Tường, "formed the ever present core of Trịnh Công Sơn's artistic personality: they were his plan for salvation, his solution to the problems of war and hatred, his way of easing the anxieties associated with the human condition" $(2001 / 1995,26)$.

Because Sơn was able to adapt and keep composing, a younger generation for whom the war was their parents' obsession, not theirs, has learned to appreciate his music. Beautiful songs like "Each Day I Choose a Piece of Happiness," "Do You Still Remember or Have You Forgotten," and "A Place for Leaving and Returning"-all written after 1975-kept the Trịnh Công Sơn phenomenon alive and projected it on a national, not just a Southern, stage. Son loved his native land so intensely and drew his inspiration from it so completely that it is difficult to imagine him succeeding as an exile songwriter. Having chosen to stay in Vietnam, if he had not been able to adapt and continue composing, he would have limited his audience greatly. You would have heard his songs in the cities of the diaspora where refugees settled, but rarely in Vietnam. Probably some of his early songs would still have been sung in Vietnam, but he would have been primarily a nostalgic figure, forever associated with the war in the South and the suffering of the 60 s and 70 s. He would not have continued to be a phenomenon. 


\section{Conclusion}

The Trịnh Công Sơn phenomenon is in part a story of an artist's relationship to political power. The U.S.'s courting of Phạm Duy, the Republic of Vietnam's banning of Trịnh Công Sơn's songs, and the Socialist Republic of Vietnam's worries after the war about what to do with Trịnh Công Sơn and his antiwar songs in the collection Songs of Golden Skin indicate that modern states are very aware of the role performing artists can play in shaping the public's response to their policies. The opposition to Trịnh Công Sơn's antiwar songs by both the RVN and the SRV suggests that states are particularly concerned with works of art that might inhibit their ability to wage war. It is Son's antiwar songs, however, works in which he opposed hatred and killing irrespective of what side the haters and killers were on, no matter how rightous they thought their cause - it is these songs that earned him the reputation of a singer who served general humanist goals not narrow political ones. And it is these songs, more than any others, that created the Trịnh Công Sơn phenomenon. In a tribute to his friend, the artist Bửu Chỉ, who lived in Huế until his death in 2002, said: "Some say we shouldn't speak about Trịnh Công Sơn's antiwar songs anymore . . . but I believe that given the upheavals of the world today [they] are still timely. They remain expressions of conscience and benevolence. No one has spoken of these things as ardently as he has. His voice should always be listened to before we launch projects that influence the lives of millions" $(2001,32)$.

The Ministry of Culture and Information is struggling, as we have seen, to prevent the circulation and performance of Trịnh Công Sơn's antiwar songs, but it has failed to prevent the return of the sad, mournful love songs that were popular in the South during the war, including songs by Trịnh Công Sơn and also songs by other composers, songs usually not as artistic or philosophical as Sơn's but equally mournful. "The return [in the 1990s] of the music of the Republic to a central place in contemporary Vietnam," argues Taylor, "provides evidence of the magnitude of their [government officials in charge of culture] failure. Its sensual rhythms, harmonies and melodies, themes of lost love, and sultry croonings of yore now dominate the soundscape of the Vietnamese public domain" $(2001,55)$. The return of this music, including the songs of Trịnh Công Sơn, suggests that these songs reflect something fundamental in the Vietnamese character. Or in the character of Vietnamese living in the area formerly known as the Republic of Vietnam? Taylor finds exoticism and nostalgia to be "central themes" of this region, themes reflected in its music. He traces this music's exoticism and "stylistic eclecticism" to the South's "history of intense foreign engagements, economic transformation and cultural reconfiguration." Its nostalgia, he argues, provides Southerners "imaginative rejections or escape routes" from these disruptions in their lives (25). Trịnh Công Sơn's songs, which, as we have seen, were perceived as new and more than a little exotic, and which often expressed nostalgia for a lost love, could be seen as welldesigned to appeal to people influenced by the history and culture of the South.

But those who live north of the $17^{\text {th }}$ parallel also love his songs. Some of the most moving tributes to Trịnh Công Sơn have come from Northerners who listened secretly to his songs during the war and were entranced by the experience (Vĩnh Nguyên 2001, Văn Cao 2001/1995, Nguyễn Duy 2001/1987, Nguyễn Văn Thọ 2001). Exoticism, stylistic eclecticism, and nostalgia would appear to be appreciated north as well as south of the $17^{\text {th }}$ parallel. Đào Duy Anh, one of Vietnam's most respected scholars - and someone who like Trịnh Công Sơn has always had an uneasy relationship to state power-is reported to have said of Trịnh Công Sơn that "he wants to take in his arms all the contradictions and hopes of the country" (qtd. by Nguyễn Đắc Xuân 2003, 123). Trịnh Công Sơn's songs may succeed because in them contradictions are combined in a pleasing artistic whole. His songs are sad and nostalgic, as Trần Hữu Thục argues, but this critic also recognizes that Sơn had an "oppositional" (nghich lý) view of human existence, a view expressed in these lines from "Close to Despair" : 
Is there something close to despair?

In life's springtime one sees the shadow of eternity.

Years long ago float to the present,

Has the river gone or just returned?

This oppositional quality is suggested by the "close to": Something close to despair is not completely hopeless. "There's a little bit of this and a little bit of that," in many Trịnh Công Sơn songs, says Cao Huy Thuần, and "a little bit of this in that" (2001b). This oppositional quality is expressed more explicitly in the lines contrasting youth and eternity, past and present, and going and coming. No doubt this quality reflects the Buddhist notion of impermanence discussed earlier. "Impermanence [vô thường] in Trịnh Công Sơn," Cao Huy Thuần says, "is no different from the idea of presence entering nothingness" (2001b, 95). And vice versa, it seems: nothingness entering presence. This same oppositional quality is reflected in Son's attitude toward death: Anticipating death leads us to love life more; death enters life and makes life more intense.

This "oppositional" way of thinking is so pronounced in Sơn's songs that one suspects from a very young age it was the way the composer viewed the world. When he was older, and his health was failing, it became very pronounced. In "I Must Not Despair" the singer tells himself not to despair but the images in this song-of leaves falling in winter, of a kite falling into an abyss-are not very consoling. Is this hope tinged with despair? Or despair tinged with hope? It's hard to say. Because Sơn recognized that the human condition was a mixture of suffering and joy, his oppositions are closer to paradoxesseeming contradictions, not real ones-because each member of a pair-love/separation, joy/sadness, life/death-contains the seed of the other member. When they were young men in Huế and the war was beginning to escalate, Hoàng Phủ Ngọc Tường says, he and Sơn believed that "art was just a way of facing death" $(2004,57)$. Throughout his life Trịnh Công Sơn kept despair at bay by representing the dualistic nature of human existence in art. Though he has passed away, his art remains. It seems certain that Vietnamese from all regions will continue to appreciate Trịnh Công Sơn for capturing the contradictions inherent in the human condition - for expressing both their troubling anxieties and their fleeting joys. 


\section{Appendix I}

\section{Vietnamese Titles of Songs}

Songs are listed in alphabetical order by English translation of the title. All songs are composed by Trịnh Công Sơn unless another song writer is mentioned. Songs with an asterisk are translated in Appendix II.

"At Night I Feel Like a Waterfall" (Đêm thấy ta là thác đổ)

"Autumn Rain Drops" (Giọt mưa thu) by Đặng Thế Phong

"Calling the Names of the Four Seasons" (Gọi tên bốn mùa)

"Carrying Vegetables to Market" (Gánh rau ra chọ))

"Close to Despair" (Gần như niềm tuyệt vọng)

*"Diễm of the Past" (Diễm xưa)

"Do You Still Remember or Have You Forgotten?" (Em còn nhớ hay em đã quên)

"Each Day I Choose a Piece of Happiness" (Mỗi ngày tôi chọn một niềm vui)

"Evening in My Native Land" (Chiều trên quê hương tôi)

"Flowers of Impermanence" (Đoá hoa vô thường)

"From a State Farm You Went to the Border" (Em ở nông trường ra biên giới)

"For Someone Who Has Fallen" (Cho một người nằm xuống)

"Huế Saigon Hanoi" (Huế Sài Gòn Hà Nội)

"I Must Not Despair" (Tôi ơi đừng tuyệt vọng)

"Join Hands in a Great Circle" (Nối vòng tay lớn)

"Let the Wind Blow It Away" (Để gió cuốn đi)

"Like a Green Marble" (Như hòn bi xanh)

"Like Words of Goodby" (Như một lời chia tay)

"Love Song of a Mad Person" (Tình ca của người mất trí)

*"Lullaby of Cannons for the Night" (Đại bác ru đêm)

"A Mother's Folk Poem" (Ca dao mẹ)

"A Mother's Legacy" (Gia tài của mẹ)

"Myths of Mother" (Huyền thoại mẹ)

"Next to a Desolate Life" (Bên đời hiu quạnh)

*"A Place for Leaving and Returning" (Một cõi đi về)

"Quiet Imprint" (Vết lăn trầm)

"Rebuild People, Rebuild Homes" (Dựng lại người dựng lại nhà)

"Remembering Autumn in Hanoi" (Nhớ mùa thu Hà Nội)

"Remembering the Wounded Soldier" (Nhớ người thương binh) by Phạm Duy

"Rise Up Vietnam" (Việt Nam ơi hãy vùng lên)

"Sad Love" (Tình sầu)

"The Sadness of Autumn Passing" (Buồn tàn thu) by Văn Cao

"Sand and Dust" (Cát bụi)

"The Sea Remembers" (Biển nhớ)

"Send the Wind to Make the Clouds Fly" (Gửi gió cho mây ngàn bay) by Đoàn Chuẩn and Từ Linh

"Singing Loudly" (Tiếng hát to) by Phạm Duy

"Singing on the Corpses" (Hát trên những xác người)

"Sleep My Child" (Ngủ đi con)

"A Song for the Corpses" (Bài ca dành cho những xác người)

"The Song of the Sand Crab" (Dã tràng ca)

"Song of a Warrior's Wife" (Chinh phụ ca) by Phạm Duy

"There'll Be a Day Like This" (Có một ngày như thế)

"To Board" (ở trọ) 
"The Tractor at the State Farm" (Máy kéo nông trường)

"The Unexpected" (Ngẫu nhiên)

"Vietnamese Girl with Golden Skin" (Người con gái Việt Nam da vàng)

"Wet Eyelashes" (Uớt mi)

"A Winter's Fable" (Ngụ ngôn của mùa đông)

"The Words of the River's Current" (Lời của dòng sông) 


\section{Appendix II}

\section{Diễm of the Past}

\begin{tabular}{|c|c|}
\hline Diễm xưa & Diễm of the Past \\
\hline Mưa vẫn mưa bay trên tầng tháp cổ & The rain still falls on the old temple \\
\hline Dài tay em mấy thuở mắt xanh xao & Your long arms, your pale eyes \\
\hline Nghe lá thu mưa reo mòn gót nhỏ & Autumn leaves fall, the sound of soft steps \\
\hline Đường dài hun hút cho mắt thêm sâu & I look in the distance, straining to see \\
\hline Mưa vẫn hay mưa trên hàng lá nhỏ & The rain still falls on small leaves \\
\hline Buổi chiều ngồi ngóng những chuyến mưa qua & In the afternoon rain I sit waiting \\
\hline Trên bước chân em âm thầm lá đổ & In your footsteps leaves quietly fall \\
\hline Chợt hồn xanh buốt cho mình xót xa & Coldness suddenly pervades my soul \\
\hline Chiều này còn mưa sao em không lại & This afternoon rain still falls why don't you come \\
\hline Nhớ mãi trong cơn đau vùi & Memories in the midst of pain \\
\hline Làm sao có nhau & How can we be with each other \\
\hline Hằn lên nỗi đau & Marks of pain appear \\
\hline Bước chân em xin về mau & I beg you to return soon \\
\hline Mưa vẫn hay mưa cho đời biển động & The rain still falls, life's like a sea storm \\
\hline Làm sao em biết bia đá không đau & How do you know a gravestone feels no pain \\
\hline Xin hãy cho mưa qua miền đất rộng & Please let the rain pass over this region \\
\hline Ngày sau sỏi đá cũng cần có nhau & In the future even stones will need each other \\
\hline Mưa vẫn hay mưa cho đời biển động & The rain still falls, life's like a sea storm \\
\hline Lam sao em nhớ những vết chim di & How do you remember traces of migrating birds \\
\hline Xin hãy cho mưa qua miền đất rộng & Please let the rain pass over this region \\
\hline Để người phiêu lãng quên mình lãng du & Let the wanderer forget he's wandering \\
\hline
\end{tabular}

Words and music by Trịnh Công Sơn; translated by

Cao Thị Như-Quỳnh and John C. Schafer 


\section{A Lullaby of Cannons for the Night}

\begin{tabular}{|c|c|}
\hline Đại bác ru đêm & A Lullaby of Cannons for the Night \\
\hline Đại bác đêm đêm dội về thành phố & Every night cannons resound in the town \\
\hline Người phu quét đường dừng chổi đứng nghe & A street cleaner stops sweeping and listens \\
\hline Đại bác qua đây đánh thức mẹ dậy & The cannons wake up a mother \\
\hline Đại bác qua đây con thơ buồn tủi & The cannons disturb a young child \\
\hline Nữa đêm sáng chói hoả châu trên núi & At midnight a flare shines in the mountains \\
\hline Đại bác đêm đêm dội về thành phố & Every night cannons resound in the town \\
\hline Người phu quét đường dừng chổi đứng nghe & A street cleaner stops sweeping and listens \\
\hline Từng chuyến bay đêm con thơ giật mình & Each flight of the planes frightens the child \\
\hline Hầm trú tan hoang ôi da thịt vàng & Destroying the shelter, tearing golden skin \\
\hline Từng đêm chong sáng là mắt quê hương & Each night the native land's eyes stay open wide \\
\hline Hằng vạn tấn bom trút xuống đầu làng & Thousands of bombs rain down on the village \\
\hline Hằng vạn tấn bom trút xuống ruộng đồng & Thousands of bombs rain down on the field \\
\hline Cửa nhà Việt Nam cháy đỏ cuối thôn & And Vietnamese homes burn bright in the hamlet \\
\hline Hằng vạn chuyến xe Clay-more lựu đạn & Thousands of trucks with Claymores and grenades \\
\hline Hằng vạn chuyến xe mang vô thị thành & Thousands of trucks enter the cities \\
\hline Từng vùng thịt xương có mẹ có em & Carrying the remains of mothers, sisters, brothers \\
\hline Đại bác đêm đêm dội về thành phố & Every night cannons resound in the town \\
\hline Người phu quét đường dừng chổi đứng nghe & A street cleaner stops sweeping and listens \\
\hline Đại bác đêm đêm tương lai rụng vàng & Every night cannons create a future without life \\
\hline Đại bác như kinh không mang lời nguyện & Cannons like a chant without a prayer \\
\hline Trẻ thơ quên sống từng đêm nghe ngóng & Children forget to live and anxiously wait \\
\hline Đại bác đêm đêm dội về thành phố & Every night cannons resound in the town \\
\hline Người phu quét đường dừng chồi đứng nghe & A street cleaner stops sweeping and listens \\
\hline Đại bác đêm đêm ru da thịt vàng & Every night cannons sing a lullaby for golden skin \\
\hline Đại bác nghe quen như câu dạo buồn & The cannons sound like a prelude to a familiar sad song \\
\hline Trẻ con chưa lớn để thấy quê hương & And children are gone before they see their native land \\
\hline
\end{tabular}

Words and music by Trịnh Công Sơn; translated by

Cao Thị Như-Quỳnh and John C. Schafer 


\section{A Place for Leaving and Returning}

\begin{tabular}{|c|c|}
\hline Một cõi đi về & A Place for Leaving and Returning \\
\hline Bao nhiêu năm rồi còn mãi ra đi & Many years I've wandered \\
\hline Đi đâu loanh quanh cho đời mỏi mệt & Going in circles, growing tired \\
\hline Trên hai vai ta đôi vầng nhật nguyệt & On my shoulders the sun and the moon \\
\hline Rọi suốt trăm năm một cõi đi về & Lighting a lifetime, a place for leaving and returning \\
\hline Lời nào của cây lời nào cỏ lạ & What word from the trees, what word from the grass \\
\hline Một chiều ngồi say một đời thật nhẹ & An afternoon of pleasure, a life that is light \\
\hline ngày qua . & A day passes \\
\hline Vừa tàn mùa xuân rồi tàn mùa hạ & First spring is gone, then summer as well \\
\hline Một ngày đầu thu nghe chân ngựa về & In early fall one hears horses returning \\
\hline chốn xa ... & To a place far away \\
\hline Mây che trên đầu và nắng trên vai & Clouds overhead and sun on the shoulders \\
\hline Đôi chân ta đi sông còn ở lại & I walk away, the river stays \\
\hline Con tinh yêu thương vô tình chợt gọi & From the spirit of love comes an unbidden call \\
\hline Lại thấy trong ta hiện bóng con người & And within myself a human shadow appears \\
\hline Nghe mưa nơi này lại nhớ mưa xa & This rain reminds me of rain long ago \\
\hline Mưa bay trong ta bay từng hạt nhỏ & It falls within me, drop by small drop \\
\hline Trăm năm vô biên chưa từng hội ngộ & Years without end and never a meeting \\
\hline Chẳng biết nơi nao là chốn quê nhà & One doesn't know which place is home \\
\hline Đường chạy vòng quanh một vòng tiều tuỵ & The road goes in circles miserable and sad \\
\hline Một bờ cỏ non một bờ mộng mị & On one side new grass, on the other dreams \\
\hline ngày xưa ... & Of the past \\
\hline Từng lời tà dương là lời mộ địa & Each sunset's call is also the grave's \\
\hline Từng lời bể sông nghe ra từ độ & In the stream one hears the call \\
\hline suối khe & Of the sea \\
\hline Trong khi ta về lại nhớ ta đi & When I return I remember leaving \\
\hline Đi lên non cao đi về biển rộng & I climb the high mountain, go down to the wide sea \\
\hline Đôi tay nhân gian chưa từng độ lượng & My arms have not yet covered the world \\
\hline Ngọn gió hoang vu thổi suốt xuân thì & In the spring of life a desolate wind blows \\
\hline Hôm nay ta say ôm đời ngủ muộn & Today I drink and wake up late \\
\hline Để sớm mai đây lại tiếc xuân thì & Tomorrow I regret the springtime I've lost \\
\hline
\end{tabular}

Words and music by Trịnh Công Sơn; translated by

Cao Thị Như-Quỳnh and John C. Schafer 


\section{Acknowledgements}

My wife, Cao Thị Như-Quỳnh, provided invaluable assistance throughout this project. The following people assisted me greatly by responding to e-mail queries regarding certain aspects of Trịnh Công Sơn's life and music: Cao Huy Thuần, Đinh Cường, Phạm Văn Đỉnh, Sâm Thương, Thái Kim Lan, and Trần Vân Mai. I would also like to thank the anonymous reviewers of an earlier draft of this article.

\section{List of References}

Bibliographic note: Books about Trịnh Công Sơn that reprint previously published articles often do not provide complete information - and sometimes provide no information-regarding the time and place of original publication. I provide all the information that the editors have made available.

Bùi Bảo Trúc. 2001. "Về Trịnh Công Sơn" (On Trịnh Công Sơn). Văn (Literature) 53 \& 54 (May/June):43-62.

Bửu Chỉ. 2001. "Nhạc phản chiến Trịnh Công Sơn" (Trịnh Công Sơn's antiwar music). Diễn đàn (Forum):110 (Sept.):29-32.

Bửu Ý. 2003. "Trịnh Công Sơn: Một nhạc sĩ thiên tài (Trịnh Công Sơn: A Genius of a Musician). Trẻ: Ho Chi Minh City.

Cao Huy Thuần. 2001a. Remarks made when introducing songs at "Đêm hoài niệm Trịnh Công Sơn" (An evening to remember Trịnh Công Sơn). Paris. 26 May.

------.. 2001b. "Buồn bã với những môi hôn" (Sadness with kisses). In Trịnh Công Sơn cát bụi lộng lấy. (Trịnh Công Sơn: Resplendent sand and dust).

-------. 2003a. "Nhạc chống chiến tranh của Trịnh Công Sơn" (Trịnh Công Sơn's music opposing the war). Remarks made when introducing songs at "Đêm Trịnh Công Sơn: Hòa Bình và Tình Yêu" (An evening of Trịnh Công Sơn: Peace and war). Paris. 3 May 2003.

------. 2003b. "Trịnh Công Sơn, từ bài hát đầu đến bài hát cuối" (Trịnh Công Sơn: From the first song to the last). Remarks made when introducing songs at "Đêm Trịnh Công Sơn: Hòa Bình và Tình Yêu" (An evening of Trịnh Công Sơn: Peace and war). Paris. 3 May.

Cổ Ngữ. 2001. "Đôi dòng về Trịnh Công Sơn" (Some lines about Trịnh Công Sơn). Văn học (Literary Studies) $186 \& 187$ (Oct./Nov.):7-14.

Đăng Tiến. 2001a. "Trịnh Công Sơn: đời và nhạc" (Trịnh Công Sơn: life and music). Văn (Literature) 53 \& 54 (May/June):9-23.

-------. 2001b. "Trịnh Công Sơn: Tiếng hát hòa bình" (Trịnh Công Sơn: Voice of peace). Văn học (Literary Studies) $186 \& 187$ (Oct./Nov.):176-200.

Đinh Cường. 2001. "Tình bạn, hồi sinh cơn hôn mê" (Friendship restores consciousness). In Trịnh Công Sơn: Cuộc đời, âm nhạc, thơ, họi họa, suy tưởng (Trịnh Công Sơn: Life, music, poetry, painting, reflections).

Đỗ Ngọc Yến. 1987. "Tâm ca Phạm Duy và phong trào du ca" (Phạm Duy's songs of the heart and the folk song movement). Văn học (Literary Studies) 21 (Oct.):118-126.

Do Vinh Tai, Joseph, and Eric Scigliano. 1997. "Love Songs of a Madman: Poems of Peace and War by Trịnh Công Sơn." In Not a War: American Vietnamese Fiction, Poetry and Essays, edited by Dan Duffy. Việt Nam Forum, no. 16. New Haven, CT: Yale University, Council on Southeast Asia Studies. 
Giao Vy. 2002. "Huế lang thang trong tháng tư" (Wandering in Huế in April). Điễn đàn 118 (May):30-32.

Gibbs, Jason. 2002. "Memories of Love." Vietnam Cultural Window 47 (Feb.):8-9.

------. 1998a. "Nhac Tien Chien: The Origins of Vietnamese Popular Song." http://www.thingsasian.com. Accessed 6 March 2003.

------. 1998b. "Reform and Tradition in Early Vietnamese Popular Song." http://www.thingsasian.com. Accessed 15 July 2003.

Hoàng Phủ Ngọc Tường. 1995/1994. "Tuyệt tình cốc" (Goodby-to-love cottage). Hợp luu (Convergences) 22 (Apr./May):52-58. Originally published in 1994.

-------. 2001/1995. "Hành tinh tình yêu thương của Hoàng tử Bé" (The little prince's planet of love). In Trịnh Công Sơn: Một người thơ ca, môt cối đi về (Trịnh Công Sơn: A singer-poet, a place for leaving and returning). Originally published as a column, called "Nhàn đàm" (Idle conversation), that Hoàng Phủ Ngọc Tường published in Thanh Niên (Youth).

-------. 2004. Trịnh Công Son và cây đàn lya của hoàng tủ bé (Trịnh Công Sơn and the lyre of the little prince). Ho Chi Minh City, Trẻ.

Jones, Andrew F. 2001. Yellow Music. Durham: Duke University Press.

Kamm, Henry. 1993. "Vietnamese Poet Sings a Song of Endurance." New York Times, 6 April.

Khánh Ly. 1988. "Huế, Tình yêu tôi" (Huế, my love). Tiếng Sông Huoong (Voice of the Perfume River):15-17.

-------. 2001. "Bên đời hiu quạnh" (Next to a melancholy life). In Trịnh Công Sơn: Một người tho $c a$, môt cõi đi về (Trịnh Công Sơn: A singer-poet, a place for leaving and returning).

-------. 2004. Interview with Bùi Văn Phú. "Khánh Ly nói về đời mình, về Trịnh Công Sơn" (Khánh Ly talks about her own life, about Trịnh Công Sơn). Văn (Literature) 92 (August):79-93.

Kierkegaard, Søren. 1941/1846. Concluding Unscientific Postscript. Trans. David Swenson. Princeton, NJ: Princeton University Press.

Lê Hữu. 2003. "Từ 'Diễm Xưa' đến 'Một Cõi Đi Về'" (From 'Diễm of the Past' to 'A Place for Leaving and Returning'). Văn học (Literary Studies) 186 \& 187 (Oct./Nov.):226-245.

Muller, René. 1998. Beyond Marginality. Westport, CT: Praeger.

Nguyễn Đắc Xuân. 2001. "Nhạc sĩ Trịnh Công Sơn với 'quê quán tôi xưa"' (Trịnh Công Sơn and 'my old native village'). In Trịnh Công Sơn cát bùi lộng lẫy (Trịnh Công Sơn: Resplendent sand and dust).

2003. Trịnh Công Sơn: Có một thời nhu thế (Trịnh Công Sơn: There was such a time). Ho Chi Minh City: Văn Học.

Nguyễn Duy. 2001/1987. "Ngày sau sỏi đá" (In the future even stones). Hợp luu (Convergences) 59 (June/July):59-65. Originally published in Tôi thích làm vua (I like being king). Ho Chi Minh City: Văn Nghệ, 1987.

Nguyễn Hoàng Văn. 2001. "Trịnh Công Sơn, khép lại một đời" (Trịnh Công Sơn: Closing a life). Hơp luu (Convergences) 59 (June/July):54-58.

Nguyen, Phong T., ed. 1991. New Perspectives on Vietnamese Music. Lac Viet Series, no. 14. New Haven, CT: Yale University, Council on Southeast Asia Studies.

Nguyễn Quang Sáng and Phạm Sĩ Sáu, eds. 2001. Trịnh Công Sơn: Nguoòi hát rong qua nhiều thế hẹ (Trịnh Công Sơn: A troubadour for many generations). Ho Chi Minh City: Trẻ.

Nguyễn Thanh Ty. 2001. "Về một quãng đời của Trịnh Công Sơn" (On a stretch of Trịnh Công Sơn's life). Văn hoc (Literary Studies) $186 \& 187$ (Oct./Nov.):208-225.

2004. Về một quãng đời Trịnh Công Sơn (On a stretch of Trịnh Công Sơn's life). 
Publisher and place of publication unknown. Apparently privately published by the author.

Nguyễn Trọng Tạo et al., eds. 2001. Trịnh Công Sơn: Một người thơ ca, một côi đi về (Trịnh Công Sơn: A singer-poet, a place for leaving and returning). Hanoi: Âm Nhạc.

2002. "Chatting about Lyrics and Music." Vietnam Cultural Window 47 (Feb.):13.

Nguyễn Văn Lực. "30 tháng 4-Đi tìm thời gian đánh mất: phần 5" (April 30-Searching for a lost time: part 5). http://dactrung.net. Accessed 15 May 2006.

Nguyễn Văn Thọ. 2001. "Nhớ Trịnh Công Sơn" (Remembering Trịnh Công Sơn). In Trịnh Công Sơn: Một người thơ ca, một cõi đi về (Trịnh Công Sơn: A singer-poet, a place for leaving and returning).

Nhật Lệ. 2001/1999. "Trịnh Công Sơn và tiềm thức 'thần phận mong manh"' (Trịnh Công Sơn and the subconscious: 'A fragile fate'). In Trịnh Công Sơn: Một người thơ ca, một côi đi về (Trịnh Công Sơn: A singer-poet, a place for leaving and returning). Originally published in Nhũng người lao động và sáng tạo (Workers and creators). Lao Động.

Nhật Tiến. 1989. "Mấy suy nghĩ của người sáng tác" (Thoughts of creative writers). Văn học (Literary Studies) 39 (Apr.):44-67.

Phạm Duy. 1990. Đương về dân ca (Returning to the folk song). Los Alamitos, CA: Xuân Thu.

-------. 1991. Hồi ký: Thời phân chia quốc cộng (Memoir: The period of division between nationalist and communist). Midway City, CA: PDC Musical Productions.

-------. 1993. "Nhạc Văn Cao" (Văn Cao's music). Hợp lưu (Convergences) 8 (Dec./Jan.):8-21.

-------. 1994. "Những bước đầu trong nửa thế kỷ âm nhạc" (The first steps in half a century of music). Hơp luu (Convergences) 19 (Oct./Nov.):70-87.

Rupp, George. 1979. Existentialism and Zen. New York: Oxford University Press.

Sâm Thương. 2004. "Đi tìm thời gian đã mất: phần I" (In search of lost times: part I). http://www.tcs-forum.org/resources/articles. Accessed 24 March 2005.

Schafer, John C. 2007. "Death, Buddhism and Existentialism in the Songs of Trịnh Công Sơn." Journal of Vietnamese Studies 2 (Winter): 144-186.

Shaplen, Robert. 1985. "Reporter at Large: Return to Vietnam II." New Yorker, 29 April.

Taylor, Philip. 2001. Fragments of the Present: Searching for Modernity in Vietnam's South. Crows Nest, Australia: Allen and Unwin.

Thái Kim Lan. 2001. "Trịnh Công Sơn, Nơi vùng ưu tư thành tiếng du ca" (Trịnh Công Sơn: Where sorrow becomes a folk song). In Trịnh Công Sơn: Cuộc đời, âm nhạc, tho; hội hoạ, suy tương (Trịnh Công Sơn: Life, music, poetry, painting, reflections).

Thanh Hải. 2001. "Anh Trịnh Công Sơn và tôi" (Trịnh Công Sơn and I). Diê̂n đàn (Forum):107 (May):38-40.

Thu Hà. 2003. "Cái gì đã thuộc về nguyên tắc thì không có ngoại lệ" (There are no exceptions to matters of principle). Tuổi trẻ (Youth), 18 April 2003. http://www.tuoitre.com.vn. Accessed 11 May 2004.

Tô Vũ. 1976. "Nhạc vàng là gì?" (What is yellow music?). Văn hóa nghệ thuật (Culture and Art) 5:43-46.

Trần Hữu Thục. 2003. "Một cái nhìn về ca từ Trịnh Công Sơn" (One view of Trịnh Công Sơn's lyrics). Văn học (Literary Studies) 186 \& 187 (Oct./Nov.):53-83.

Trần Thùy Mai et al., eds. 2001. Trịnh Công Sơn cát bùi lộng lẫy (Trịnh Công Sơn: Resplendent sand and dust), edited by Trần Thùy Mai et al. Huế: Thuận Hóa.

Trần Tuyết Hoa. "40 năm hành trình âm nhạc: Trịnh Công Sơn, Thái Hòa và tôi" (A Forty-year Musical Journey: Trịnh Công Sơn, Thái Hòa and Me). http://www.chuyenluan.net. Accessed 7 May 2006. 
Trịnh Công Sơn. 1972. "Thay lời tựa" (In lieu of an introduction). In Tụ tình khúc (Songs expressing love). Saigon: Nhân bản. Reprinted as "Tin vào niềm tuyệt vọng" (Believing in despair) in Trịnh Công Sơn: Một người thơ ca, một cõi đi về (Trịnh Công Sơn: A singerpoet, a place for leaving and returning).

-------. 2003/1978. "Nam Thạch Hãn những ngày đầu tháng ba" (Some days in early March [1978] along the southern Thạch Hãn). In Trịnh Công Sơn: Có một thời nhu thế (Trịnh Công Sơn: There was such a time). Originally published in Văn nghệ, Bình Trị Thiên (Literature and Art, Bình Trị Thiên): 9 July 1978.

. 2003/1987a. "Thời kỳ trốn lính" (My draft dodging period). In Trịnh Công Sơn: Có môt thời nhu thế (Trịnh Công Sơn: There was such a time). Originally published in 1987.

-------. 2003/1987b. "Nỗi ấm mảnh thời thơ ấu" (Warm memories of youthful obsessions). In Trịnh Công Sơn: Có một thời nhu thế (Trịnh Công Sơn: There was such a time). Originally published in 1987.

-------. 2001/1989. Interview with Lũ Quỳnh. "Tôi đã tận hưởng những tình cảm nhân loại" (I have fully enjoyed the human emotions). In Trịnh Công Son: Một nguời tho ca, một cố đi $v \hat{e}$ (Trịnh Công Sơn: A singer-poet, a place for leaving and returning). Originally appeared in Cửa số văn hóa (Vietnam Cultural Window) (May).

2001/1990. "Bài hát đầu tiên bài hát cuối cùng" (The first song, the last song). In Trịnh Công Sơn: Cuộc đời, âm nhạc, tho, hội hoạ, suy tưởng (Trịnh Công Sơn: Life, music, poetry, painting, reflections).

------. 2001/1993. "Nhớ lại" (Looking back). In Trịnh Công Sơn: Người hát rong qua nhiều thế $h \hat{e}$ (Trịnh Công Sơn: A troubadour for many generations). Originally published in Báo Sài Gòn Giải Phóng (Saigon Liberation) (30 Apr.).

-------. 2001/1997a. "Để bắt đầu một hồi ức" (To begin a recollection). In Trịnh Công Sơn: Một người tho ca, một cõi đi về (Trịnh Công Sơn: A singer-poet, a place for leaving and returning). Originally published in Thế giới âm nhạc (The world of music) (Jan.).

------. 2001/1997b. "Hồi ức" (Recollections). In Trịnh Công Sơn: Một người tho ca, một cõi đi $v \hat{e}$ (Trịnh Công Sơn: A singer-poet, a place for leaving and returning). Originally published in Thế giới âm nhac (The world of music) (Mar.). 2001/1997c. "Hồi ức về một nhạc phẩm-Hạ trắng" (Recollection on the work 'White Summer'). In Trịnh Công Sơn: Cuộc đời, âm nhạc, tho; hội họa, suy tuởng (Trịnh Công Sơn: Life, music, poetry, painting, reflections). Originally published in Thế giới âm nhạc (The world of music) (May).

-------. 2001/1998. Interview with Văn Cầm Hải. "Kiếp sau tôi vẫn là người nghệ sĩ" (I'll still be an artist/writer in my next reincarnation). In Trịnh Công Sơn: Một người tho ca, một côi đi $v \hat{e}$ (Trịnh Công Sơn: A singer-poet, a place for leaving and returning). Place and date of original publication not given.

. 2001/2000. Interview with Hoài Anh. "Trịnh Công Sơn, Góp lá mùa xuân" (Trịnh Công Sơn: Gathering spring leaves). In Trịnh Công Sơn: Người hát rong qua nhiều thể hệ (Trịnh Công Sơn: A troubadour for many generations). Originally published in Báo Văn Nghệ Thành Phố Hồ Chí Minh (Literature and Art of Ho Chi Minh City) (Spring). 2001/n.d. [a]. "Nhớ về một bài hát" (Remembering a song). In Trịnh Công Sơn: Một người tho ca, một cõi đi về (Trịnh Công Sơn: A singer-poet, a place for leaving and returning). Place and date of original publication not given.

2001/n.d. [b]. "Phác thảo chân dung tôi" (Sketching a self-portrait). In Trịnh Công Son: Một người tho ca, một cõi đi về (Trịnh Công Sơn: A singer-poet, a place for leaving and 
returning). Originally published in Nhạc và đời (Music and life) ( Hậu Giang Publishing House, n.d.).

-------. 2001/n.d. [c]. Interview with Quốc Hưng. "Âm nhạc mùa xuân tình yêu" (Music in the spring of love). In Trịnh Công Sơn: Một người thơ ca, một cõi đi về (Trịnh Công Sơn: A singer-poet, a place for leaving and returning). Place and date of original publication not given.

Trịnh Cung. 2001. "Bi kịch Trịnh Công Sơn" (The tragedy of Trịnh Công Sơn). Văn (Literature) 53 \& 54 (May/June):77-83.

Trịnh Cung and Nguyễn Quốc Thái. 2001. Trịnh Công Sơn: Cuộc đời, âm nhạc, tho; hội hoạ, suy tuởng (Trịnh Công Sơn: Life, music, poetry, painting, reflections). Ho Chi Minh City: Văn Nghệ.

Tuấn Huy. 2001. "Trịnh Công Sơn, cỏ xót xa người" (Trịnh Công Sơn: the painful grass of humanity). Văn học (Literary Studies) $186 \& 187$ (Oct./Nov.):28-38.

Văn Ngọc. 2001. "Trịnh Công Sơn, Khánh Ly \& những khúc tình ca một thời" (Trịnh Công Sơn, Khánh Ly, and the love songs of an era). Điễn đàn (Forum) 110 (Sept.):26-28.

Vĩnh Nguyễn. 2001. "Hồi ức về Trịnh Công Sơn" (Recollections regarding Trịnh Công Sơn). In Trịnh Công Sơn cát bùi lộng lây (Trịnh Công Sơn: Resplendent sand and dust). 